CHPRC-01590

Revision 0

\title{
Potential Benchmarks for Actinide Production in Hanford Reactors
}

Prepared for the U.S. Department of Energy

Assistant Secretary for Environmental Management

Contractor for the U.S. Department of Energy

under Contract DE-AC06-08RL14788

\section{CH:H2NHLL}

Plateru Remodiation Company

P.O. Box 1600

Richland, Washington 99352

Approved for Public Release;

Further Dissemination Unlimited 
CHPRC-01590

Revision 0

\section{Potential Benchmarks for Actinide Production in Hanford Reactors}

Document Type: RPT

R. J. Puigh

CH2M HILL Plateau Remediation Company

H. Toffer

TRS

Date Published

October 2011

Prepared for the U.S. Department of Energy

Assistant Secretary for Environmental Management

Contractor for the U.S. Department of Energy

under Contract DE-AC06-08RL14788

\section{COHZ2IVHILLL}

Prateru Remediation Compary

P.O. Box 1600

Richland, Washington

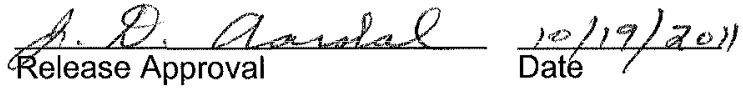


CHPRC-01590

Revision 0

TRADEMARK DISCLAIMER

Reference herein to any specific commercial product, process, or service by trade name, trademark, manufacturer, or

otherwise, does not necessarily constitute or imply its

endorsement, recommendation, or favoring by the United

States Government or any agency thereof or its contractors or subcontractors.

This report has been reproduced from the best available copy.

Printed in the United States of America 


\title{
Potential Benchmarks for Actinide Production in Hanford Reactors
}

\author{
Prepared by: R. J. Puigh and H. Toffer \\ for \\ CH2M HILL Plateau Remediation Company \\ Richland, Washington
}

October 2011 
CHPRC-01590, Revision 0

This page is intentionally left blank. 


\section{TABLE OF CONTENTS}

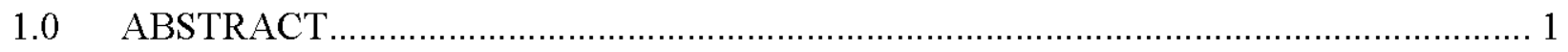

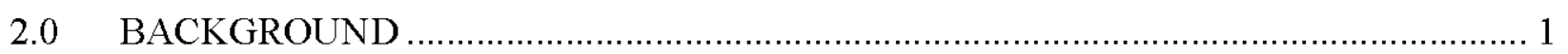

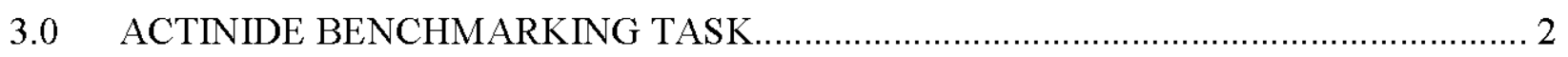

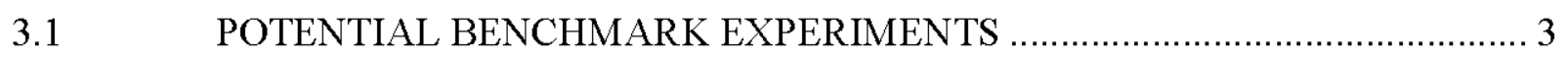

3.2 IDENTIFICATION OF INFORMATION NEEDED FOR PROPOSED

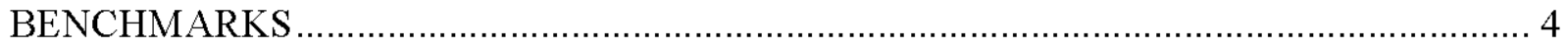

4.0 EXAMPLE BENCHMARK INPUT INFORMATION ......................................... 4

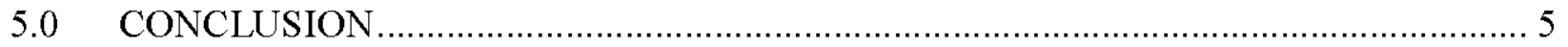

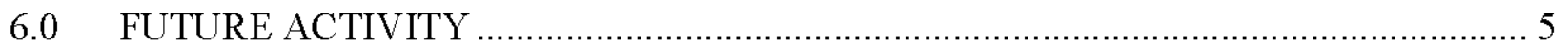

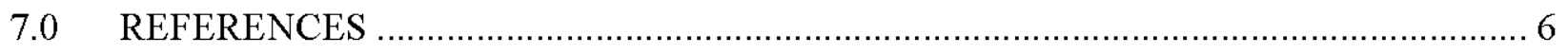

\section{LIST OF FIGURES}

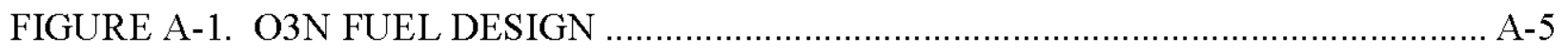

FIGURE A-2. LOCATION OF PROCESS TUBES COMPRISING THE PTA-069 EXPERIMENT IN THE B REACTOR

FIGURE A-3. CORRECTED ACTIVITY VS. FUEL ELEMENT POSITION FOR REACTOR LOCATION 1279

FIGURE A-4. CORRECTED ACTIVITY VS. FUEL ELEMENT POSITION FOR REACTOR LOCATION 1180 .

FIGURE A-5. RELATIVE GROSS GAMMA SCAN INTENSITY VS. FUEL ELEMENT POSITION FOR PROCESS TUBE 0582 ............................................ A-14

FIGURE A-6. RELATIVE GROSS GAMMA SCAN INTENSITY VS. FUEL ELEMENT POSITION FOR PROCESS TUBE 1078.

FIGURE A-7. RELATIVE GROSS GAMMA SCAN INTENSITY VS. FUEL ELEMENT

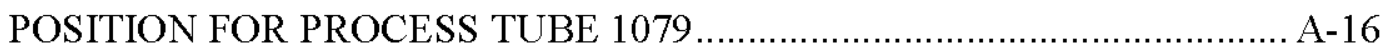

FIGURE A-8. RELATIVE GROSS GAMMA SCAN INTENSITY VS. FUEL ELEMENT POSITION FOR PROCESS TUBE 1179.

FIGURE A-9. RELATIVE GROSS GAMMA SCAN INTENSITY VS. FUEL ELEMENT POSITION FOR PROCESS TUBE 1378 A-18

FIGURE B-1. B REACTOR GRAPHITE STACK KEYING AND SELECTED DIMENSIONS B-4

FIGURE B-2. PROCESS TUBE CROSS-SECTION B-6 


\section{LIST OF TABLES}

TABLE 1. TABULATION OF DEVELOPMENT AND PRODUCTION TESTS ….................. 3

TABLE A-1. DIMENSIONS FOR O3N FUEL AND O3W WATER MIX ELEMENT ......... A-5

TABLE A-2. INITIAL URANIUM ISOTOPIC CONCENTRATIONS IN PTA-069 SPECIAL TEST FUEL ELEMENTS A-7

TABLE A-3. OPERATING DATA FOR THE PTA-069 EXPERIMENT …………............. A-10

TABLE A-4. SPECIMEN ID\# AND RADIOCHEMICAL RECORD NUMBERS FOR PTA-

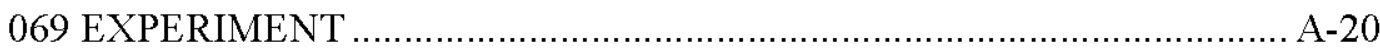

TABLE A-5. FINAL U ISOTOPIC CONCENTRATIONS IN IRRADIATED FUEL FROM THE PTA-069 EXPERIMENT............................................................... A-21

TABLE A-6. FINAL PU ISOTOPIC CONCENTRATIONS IN IRRADIATED FUEL FROM THE PTA-069 EXPERIMENT. A-21

TABLE A-7. FINAL URANIUM, PLUTONIUM, AND NEPTUNIUM CONCENTRATIONS

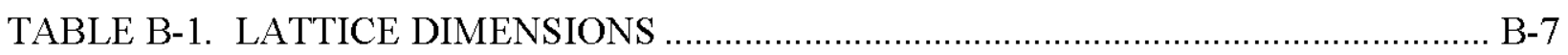

TABLE B-2. LATTICE COMPOSITION ………………………………………..... B-7 


\section{LIST OF ACRONYMS}

$\begin{array}{ll}\text { Al } & \text { aluminum } \\ \text { HCR } & \text { Horizontal Control Rods } \\ \text { KE } & \text { K East } \\ \text { KW } & \text { K West } \\ \text { LEU } & \text { low enriched uranium } \\ \text { MW } & \text { megawatt } \\ \text { PCCF } & \text { Poison Column Control Facility } \\ \text { PT } & \text { process tube } \\ \text { Pu } & \text { plutonium } \\ \text { SPR } & \text { Single Pass Reactor } \\ \text { TWFM } & \text { Traveling Wire Flux Mapping } \\ \text { TP } & \text { tube powers } \\ \text { U } & \text { uranium } \\ \text { VSR } & \text { Vertical Safety Rods } \\ \text { Zr } & \text { zirconium }\end{array}$


CHPRC-01590, Revision 0

\subsection{ABSTRACT}

A significant experimental program was conducted in the early Hanford reactors to understand the reactor production of actinides. These experiments were conducted with sufficient rigor, in some cases, to provide useful information that can be utilized today in development of benchmark experiments that may be used for the validation of present computer codes for the production of these actinides in low enriched uranium fuel.

\subsection{BACKGROUND}

The nine Hanford production reactors were all graphite moderated and assembled out of interlocking graphite blocks forming a large cube (See Appendix B for representative graphite stack schematic for B Reactor). Allowing for shielding, the cuboid was $38 \mathrm{ft}$ by $44 \mathrm{ft}$ by $46 \mathrm{ft}$. The fuel was in horizontal process tubes penetrating the core in the front to rear direction. The process tubes were initially made out of aluminum ( $\mathrm{Al}$ ) or $\mathrm{Al}$ alloy (and later a zirconium $[\mathrm{Zr}]$ alloy). These process tubes were arranged in a definite lattice pattern. Vertical safety and horizontal control rods, inside separate channels, penetrated the core from the top to the bottom and side to side, respectively. Cooling water was pumped through the process tubes to remove the heat. As the need for special isotopes increased, more reactors were built.

All reactors were erected close to the Columbia River for a supply of cooling water. The first reactors were known as the small Single Pass Reactors (SPR), followed by the large SPRs K East $(\mathrm{KE})$ and $\mathrm{K}$ West $(\mathrm{KW})$ and finally the $\mathrm{N}$ Reactor which had a re-circulating primary coolant loop. Initial pile designs were conservative with low design power levels. As operating experiences increased, power levels were gradually raised. By 1964, nine production reactors were in operation at elevated power levels beyond original design values. The $\mathrm{KE}$ and $\mathrm{KW}$ Reactors were the largest reactors at Hanford capable of accommodating multiple isotope missions.

The objective of an isotope production reactor is to transmute material to a uniform product, a product that can be replicated from one discharge to the next or from one reactor to the other. Isotope production can be monitored by operating to specified process tube powers (TP). Tubes are selected for discharge so that average product quality of the discharged fuel meets specific objectives. In the Hanford vernacular, a specific listing of process tubes to be charged and discharged into a given reactor was called a key. The quality and quantity of material for a key is determined by tracking the power output per tube. Each tube outlet temperature and flow was measured. From flow and temperature, tube exposure can be determined. Generally, production tables were prepared for each reactor to facilitate plutonium $(\mathrm{Pu})$, uranium $(\mathrm{U})$, and other isotope tracking. Exposure of a single fuel element can be determined using the element location number, tube flow, temperature rise, and the nearest axial neutron flux profile or gamma scans of the process tube contents. The power output of a process tube can also be obtained by analyzing a fuel element for actinides that impact the heat output.

To evaluate fuel exposure and build-up of actinides, detailed knowledge of reactor configuration, as well as operations, was needed. Neutron flux and spectrum were important quantities for 
monitoring depletion and build-up of fissionable isotopes and of fission products. There was a basic premise in the reactor design that the reactors needed to be designed to operate using metallic natural uranium fuel and that they could be cooled with light water. The outer ring of process tubes in later operations were loaded with slightly enriched $0.95 \mathrm{wt} \% \mathrm{U}-235$ metallic low-enriched uranium (LEU) fuel elements to level the neutron flux in the later operation of some Hanford reactors. Slightly positive reactivity was maintained in the core using horizontal control rods and other neutron absorbers. The objective of the reactor operation was to produce $\mathrm{Pu}$ with a pre-described discharge average $\mathrm{Pu}$ isotopic concentration.

To determine the extent of transmutations in the reactor fuel requires knowledge of how long the materials have been exposed to neutron flux and its associated energy spectrum. Early flux monitoring in the core utilized flux monitoring splines that could be inserted into selected process tubes to measure axial flux profiles. Later, the Traveling Wire Flux Mapping (TWFM) system was used to monitor axial neutron flux in the core at selected locations. The average flux in the SPR core proper was approximately $1 \times 10^{14}$ neutrons $/ \mathrm{cm}^{2} / \mathrm{sec}$ as measured by flux wires (UNI-2592).

In the late 1940's to mid 1960's, reactor development work and planning for new missions relied heavily on radiochemical experimental measurements. Present day reactor physics codes were not available; however, state-of-the-art radiochemistry was in use and was applied to chemical measurements of actinide concentrations in targets or fuel elements.

\subsection{ACTINIDE BENCHMARKING TASK}

An effort is underway to process past radio-chemical data and to extract useful neutronic information from it. This task could also provide very useful benchmark-like data for burn-up credit development and implementation. Currently, transmutation data for a LEU system as a function of burn-up is scarce. Some of the past data could be directly applicable to reactor design efforts or the handling and storage of spent fuel. No matter what the application, validation of present day codes is important. Therefore, availability of reactor dimensions as well as operating conditions and isotopics are essential. A concentrated effort to obtain references which contain the above needed data has been undertaken. Special data bases were established and published in CHPRC-NS-09-026, Actinide Cross-Section Extraction Status Report 1, and CHPRC-01335, Relevant Reactor Operations Data Quarterly Letter Report.

The purpose of the benchmark task is to compile available data on selected experiments performed in the Hanford reactors and make a determination if sufficient data are available to support computer modeling of actinide production that could be compared to experimental results. Sufficient data are needed to define the irradiation conditions. Also data are needed so that the sensitivity of the results to the irradiation conditions are understood and can be adequately addressed in the modeling.

The scope of this report is to list experiments conducted in the Hanford reactors that could be potentially developed into benchmarks for actinide production. The scope includes the development of benchmark-like information for one experiment, PTA-069, to evaluate the adequacy of the information readily available for a literature search from relevant information. Key to this evaluation is the level of information that is publicly available. 


\subsection{POTENTIAL BENCHMARK EXPERIMENTS}

From these databases a listing of experiments and their corresponding data have been compiled. Table 1 provides a preliminary listing of experiments that may have sufficient information to be used as a benchmark.

TABLE 1. TABULATION OF DEVELOPMENT AND PRODUCTION TESTS

\begin{tabular}{|c|c|c|c|c|c|}
\hline $\begin{array}{c}\text { Test } \\
\text { Number }\end{array}$ & Doc. Title & Reactor & Year & Where & $\begin{array}{c}\text { Radio- } \\
\text { chemical } \\
\text { Data } \\
\text { Available }\end{array}$ \\
\hline PTA-069 & $\begin{array}{l}\text { Controlled }{ }^{236} \mathrm{U} \text { and }{ }^{237} \mathrm{~Np} \\
\text { Production Test in O3N Fuel }\end{array}$ & B & $\begin{array}{c}1967- \\
1968 \\
\end{array}$ & In Fuel & Yes \\
\hline PTA-084 & $\begin{array}{l}\text { High Exposure Engineering Test } \\
\text { on O3N Fuel }\end{array}$ & $\mathrm{B}$ & & $\begin{array}{l}\text { In Fuel } \\
\text { Eng. Test }\end{array}$ & Yes \\
\hline PTA-054 & $\begin{array}{l}\text { Not of Interest - T Production in } \\
\text { Lithium } 2.1 \mathrm{U} \text {-metal block }\end{array}$ & KW & & Target & Yes \\
\hline PTA-137 & $\begin{array}{l}\text { Thorium Irradiation Supported by } \\
\text { Enriched Metal K5E }\end{array}$ & $\mathrm{KW}$ & & Target & Yes \\
\hline PTA-107 & $\begin{array}{l}\text { Controlled }{ }^{236} \mathrm{U} \text { and }{ }^{237} \mathrm{~Np} \\
\text { Production Test in K5E Fuel }\end{array}$ & $\mathrm{KE}$ & & In Fuel & Yes \\
\hline PTA-48 & $\begin{array}{l}\text { Depleted Uranium Irradiation } \\
\text { Test K5D Fuel }\end{array}$ & $\mathrm{KE}$ & & In Fuel & Yes \\
\hline PTA-103 & $\begin{array}{l}\text { Overbore Block Test on Tube and } \\
\text { Rod Fuel CMZE, CMIE fuel }\end{array}$ & $\mathrm{C}$ & & $\begin{array}{l}\text { In Fuel } \\
\text { Eng. Test }\end{array}$ & Yes \\
\hline PTA-068 & $\begin{array}{l}\text { Final Report PT- } 68 \text { Results of N- } \\
\text { Reactor Neptunium Irradiation }\end{array}$ & $\mathrm{N}$ & & In Fuel & Yes \\
\hline PT-NR-68 & $\begin{array}{l}\text { Production of } \mathrm{Pu}-238 \text { from } \\
\text { Hanford-generated Np using the } \\
\text { N Reactor }\end{array}$ & & $\begin{array}{l}1969- \\
1972\end{array}$ & Target & $\begin{array}{l}\text { Under } \\
\text { record } \\
\text { review }\end{array}$ \\
\hline PTA-063 & $\begin{array}{l}\text { Quick turnaround } \mathrm{Np} \\
\text { demonstration }\end{array}$ & & 1969 & Target & $\begin{array}{l}\text { Under } \\
\text { record } \\
\text { review }\end{array}$ \\
\hline PTA-163 & Clean ${ }^{238} \mathrm{Pu}$ & & 1969 & & $\begin{array}{l}\text { Under } \\
\text { record } \\
\text { review }\end{array}$ \\
\hline PT-NR-113 & 94 Metal high ${ }^{236} \mathrm{U}$ & & & In Fuel & $\begin{array}{l}\text { Under } \\
\text { record } \\
\text { review }\end{array}$ \\
\hline PTA-209 & Improved $\mathrm{Np}$ target & & & Target & $\begin{array}{l}\text { Under } \\
\text { record } \\
\text { review }\end{array}$ \\
\hline PT-NR-107 & Central Zone Loading of Mark IV & $\mathrm{N}$ & & In Fuel & $\begin{array}{l}\text { Under } \\
\text { record } \\
\text { review }\end{array}$ \\
\hline
\end{tabular}


CHPRC-01590, Revision 0

\begin{tabular}{|c|l|c|c|c|c|}
\hline $\begin{array}{c}\text { Test } \\
\text { Number }\end{array}$ & Doc. Title & Reactor & Year & Where & $\begin{array}{c}\text { Radio- } \\
\text { chemical } \\
\text { Data } \\
\text { Available }\end{array}$ \\
\hline PTA-150 & $10 \mathrm{~kg} \mathrm{Pu} \mathrm{Al}$ & & 1970 & Target & $\begin{array}{c}\text { Under } \\
\text { record } \\
\text { review }\end{array}$ \\
\hline PT-105-516 & $\begin{array}{l}\text { An Effect of Metallurgy on Th } \\
\text { Targets }\end{array}$ & KE & 1953 & Target & $\begin{array}{c}\text { Under } \\
\text { record } \\
\text { review }\end{array}$ \\
\hline PT-171 & Irradiation of Americium & KE & $\begin{array}{c}1969- \\
1970\end{array}$ & Target & No \\
\hline
\end{tabular}

\subsection{IDENTIFICATION OF INFORMATION NEEDED FOR PROPOSED BENCHMARKS}

To support the use of these experiments as potential code benchmarks, significant detailed information will be needed on the reactor and the reactor operations during the period of time the experiment was loaded into the reactor. Also, specific experimental information must be compiled to describe the pre-irradiation characterization of the experimental fuel, the details of its loading into the B Reactor, operations details, and post-irradiation characterization of the irradiation conditions and the isotopic analyses performed on selected fuel elements.

The information needed for proposed code validation was developed from the review of the types of information as defined in Evaluation Guide for the International Reactor Physics Experiments Evaluation Project (NEA/NSA/DOC[2006]2). Because the experimental information needed for this type of benchmark is somewhat different from information needed for critical experiment benchmarks, the data needs and evaluation criteria were modified slightly from those identified in NEA/NSA/DOC[2006]2. Greater emphasis was placed on describing the reactor and reactor environment.

\subsection{EXAMPLE BENCHMARK INPUT INFORMATION}

This report provides a detailed review of the readily available information on the PTA-069Neptunium-237 Production from Natural Uranium with a High U-236 Content (DUN-2441). Relevant benchmark information on the detailed description of this experiment and a preliminary evaluation of the experimental data are provided in Appendix A. Appendix A also includes relevant information on the $\mathrm{B}$ Reactor as part of the detailed description of the experiment. 


\subsection{CONCLUSION}

Significant benchmark-like, quality data exists for the PTA-069 experiment. Initial data gaps have been identified and are summarized below:

- Specific core loading information for duration of test (Should be available in records)

- The burn-up in the fuel for the process tubes in the immediate area of the experimental process tubes

- The degree of non-uniformity in the graphite stack during the experiment irradiation.

\subsection{FUTURE ACTIVITY}

The following future activities are planned:

- Determine whether or not gaps need to be addressed

- Consider other tests for adequate data quality to be considered as benchmarks 
CHPRC-01590, Revision 0

\subsection{REFERENCES}

1. UNI-2592, 1986, Pu-238 Production from Initial U-236 in MKIV Fuel Based on Measurement, W. D. Wittekind and J. Clayhold, UNC Nuclear Industries, Richland, Washington, September 1986.

2. CHPRC-NS-10-001, Hanford 1P\&D Subtask3: Actinide Cross-Section Extraction Status Report 1, H. Toffer, CH2M HILL Plateau Remediation Company, Richland, Washington, 2010.

3. CHPRC-01335, Relevant Reactor Operations Data Quarterly Letter Report, H. Toffer and R. J Puigh, CH2M HILL Plateau Remediation Company, Richland, Washington, April 2011.

4. NEA/NSA/DOC[2006]2, Evaluation Guide for the International Reactor Physics Experiments Evaluation Project, Revision 8.10, Organization for Economic Co-operation and Development, 2006.

5. DUN-2441, PTA-069 - Neptunium-237 Production from Natural Uranium with a High U-236 Content, J. P. Schmitt and H. Toffer, Douglas, United Nuclear, Inc., Richland, Washington, May 1967. 
CHPRC-01590, Revision 0

APPENDIX A

PTA-069, NEPTUNIUM-237 PRODUCTION FROM NATURAL URANIUM WITH A HIGH U-236 CONTENT 
CHPRC-01590, Revision 0

This page is intentionally left blank. 
CHPRC-01590, Revision 0

\section{A1.0 DETAILED DESCRIPTION}

The object of the PTA-069 experiment was to conduct a controlled experiment to determine the neptunium production in uranium from different uranium precursors over a range of exposures and in different neutron spectra.

\section{A1.1 Description of the Configuration}

\section{A1.1.1 Overview of the Experiment}

$\mathrm{Np}-237$ is formed in the production reactors by several possible neutron capture reactions in uranium. The quantitative data currently in existence for these reactions are applicable to low U236 assays in enriched uranium and only a narrow range of exposures. By irradiating natural uranium fuel elements with two different U-236 contents ( 6 and $400 \mathrm{ppm} \mathrm{U-236)} \mathrm{to} \mathrm{various}$ exposures in two different reactor locations, the rate of formation of Np-237 from the various reactions can be determined. The most important information to be gained from this experiment include:

- $\quad$ U-236 formation in natural uranium fuel as a function of exposure

- Establishment of the exposure dependence of neptunium production from its various uranium precursors

- $\quad$ Neptunium production as a function of original fuel U-236 content

- Determination and verification of any resonance shielding effects between U-236 and U-238

- $\quad$ Neutron spectrum effects on U-236 formation and on neptunium production

\subsubsection{Geometry of the Experiment Configuration and Measurement Procedure}

The PTA-069 experiment (DUN-2441) was designed to determine the neptunium production in uranium from various uranium precursors over a range of exposures and in different neutron spectra. By irradiating natural uranium fuel elements with two different U-236 contents, nominally 6 and $400 \mathrm{ppm}$ U-236, to various exposures and in two different reactor locations, the rate of formation of $\mathrm{Np}-237$ from the various reactions can be determined.

\subsubsection{Experiment Configuration}

Twelve fuel columns with O3N fuel design were used in this experiment. The O3N type fuel was fabricated from natural uranium metal cores with nominally $6 \mathrm{ppm}$ U-236 isotope (control elements) and natural uranium metal with 400 ppm U-236.

The experiment utilized 12 fuel columns (assemblies) of O3N fuel elements (Figure A-1, O3N Fuel Design). Each fuel column was comprised of 14 special test fuel elements and either 18 or 12 standard fuel elements that were used to center the special test fuel elements around the center of the reactor core mid-plane. The special test fuel elements had the standard O3N fuel design and the fuel were fabricated from two special natural uranium ingots that were prepared for this test to permit fixing and accurate determination of the uranium isotopic composition for the test 
fuel elements. These ingots utilized virgin uranium metal and recycled natural uranium with elevated U-236 concentrations.

From (DUN-2441) and (DUN-7243 RD) each fuel column contained seven test fuel elements fabricated from natural uranium cores with a nominal $6 \mathrm{ppm}$ U-236 isotope concentration and seven test fuel elements fabricated from natural uranium cores with a nominal $400 \mathrm{ppm}$ U-236 isotope concentration. The special test fuel design and material compositions are provided below. Within each fuel column the special test fuel elements were loaded alternating the high and low U-236 content elements.

The lower exposure assemblies, designed for 300, 600, and $900 \mathrm{MWD} /$ ton irradiation exposures, were comprised of seven, 32-piece fuel element columns with the 14 special test fuel elements located in the center of the fuel column and 9 standard fuel elements on each end of the fuel column. The seven, 32-piece columns include a $03 \mathrm{~W}$ water mix element in position seven and were charged with the standard 133-inch downstream dummy pattern and were loaded into seven process tubes.

The higher exposure assemblies, designed for 1200, 1500, and $1800 \mathrm{MWD} /$ ton irradiation exposures, are comprised of five, 24-piece fuel element columns with the 14 special test fuel elements located in the center of the fuel column and six standard fuel elements on each end of the fuel column. The shorter column lengths and utilization of 0.377 -inch venturies allowed for increased flow in these tubes which, reduced power generation of the shorter columns and provided a reduction in cladding and coolant temperatures to minimize the risk of failure at these higher exposures. The five, 24-piece columns did not contain any water mixers and were charged with 165-inch downstream dummy pattern and were loaded into five process tubes.

Figure A-1 for the design is provided below. The dimensions of test fuel elements are also provided in Table A-1 below, Dimensions for O3N Fuel and 03W Water Mix Element. 


\section{FIGURE A-1. O3N FUEL DESIGN}

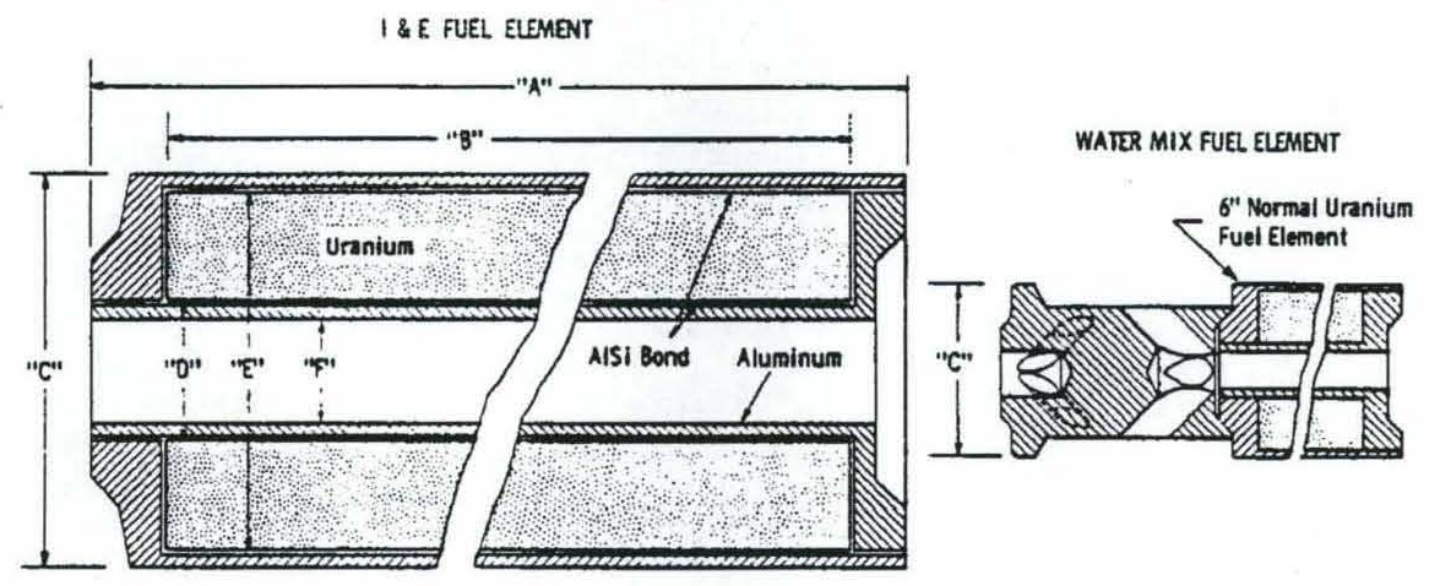

TABLE A-1. DIMENSIONS FOR O3N FUEL AND O3W WATER MIX ELEMENT

\begin{tabular}{|c|c|c|c|c|}
\hline $\begin{array}{l}\text { Dimension } \\
\text { Label }\end{array}$ & $\begin{array}{l}\text { Nominal O3N } \\
\text { fuel dimension } \\
\text { (inches) }\end{array}$ & $\begin{array}{l}\text { Tolerances } \\
\text { (inches) }\end{array}$ & $\begin{array}{l}\text { Nominal O3W Water } \\
\text { Mix dimension } \\
\text { (inches) }\end{array}$ & $\begin{array}{l}\text { Tolerances } \\
\text { (inches) }\end{array}$ \\
\hline A & 8.965 & $\begin{array}{l}+0.120 \\
-0.080\end{array}$ & 6.640 & $\begin{array}{l}+0.120 \\
-0.080\end{array}$ \\
\hline $\mathrm{B}$ & 8.378 & \pm 0.010 & 6.053 & \pm 0.010 \\
\hline $\mathrm{C}$ & 1.444 & \pm 0.006 & 1.443 & \pm 0.006 \\
\hline $\mathrm{D}$ & $0.423^{\mathrm{a}}$ & \pm 0.004 & 0.423 & \pm 0.004 \\
\hline $\mathrm{E}$ & 1.356 & $\begin{array}{l} \pm 0.001 \\
-0.002\end{array}$ & 1.356 & $\begin{array}{l} \pm 0.001 \\
-0.002\end{array}$ \\
\hline $\mathrm{F}$ & 0.310 & \pm 0.006 & 0.037 & \pm 0.006 \\
\hline $\begin{array}{l}\text { Nominal Can } \\
\text { Wall Thickness } \\
\text { a }\end{array}$ & 0.037 & --- & 0.037 & --- \\
\hline $\begin{array}{l}\text { Nominal Spire } \\
\text { Wall Thickness } \\
\text { a }\end{array}$ & 0.050 & --- & 0.050 & --- \\
\hline
\end{tabular}




\subsubsection{Measurement Procedure}

To support the development of relevant benchmark data the following measurement information have been identified:

- Pre-irradiation characterization of the fuel

- Relevant reactor operation parameters

- Post irradiation examination of irradiated fuel elements

The pre-irradiation characterization of the fuel includes the following material information on the fuel elements: aluminum fuel cladding composition, the uranium ingot composition and isotopic data, and the fuel element dimensions with tolerances. The details of the material data are provided in Section 1.1.3. The dimensional information is assumed to meet the specifications provided in Table A-1. DUN-2441 indicates the Production Fuels Section has responsibility for pre-irradiation measurements and marking of the fuel used in this experiment. Additional characterization of the test fuel elements may reside in other records from that period, if needed.

Relevant reactor operation parameters include:

- the core loadings for the particular period of time the PTA-069 experiment was in the reactor core,

- the process tube inlet and outlet temperatures and set-points,

- the neutron flux in regions near the PTA-069 experiment process tubes,

- the reactor power history, and

- the cumulative exposures on each process tube containing the PTA-069 experiment.

The PTA-069 experiment test loading is shown in Figure A-.2, Location of Process Tubes Comprising the PTA-069 Experiment in the B Reactor, (Test 1 in Figure A-2). The seven lowexposure assemblies were loaded into process tubes at locations: 1079, 1178, 1179, 1181, 0582, 1280 and 1380. The five high-exposure assemblies ere loaded into process tubes at locations: $1078,1378,1278,1279$ and 1379.

Relevant information may also include specific fuel loading (and estimated burn-up) for fuel adjacent to the process tubes containing the PTA-069 experiment. Such core loading information should be available in the Hanford records repository.

Process tube inlet and outlet temperatures were continuously monitored for the PTA-069 experiment process tubes and daily records are provided in DUN-3612-RD.

The neutron flux in the process tube locations 1279 and 1180 (Figure A-2) were measured and details provided in Section 1.3. The reactor power history and cumulative exposures for the PTA-069 experiment fuel elements were recorded and summarized in Table A-.3, Operating Data for the PTA-069 Experiment, (from DUN-7243-RD).

Post-irradiation examination of selected fuel elements is discussed in Section 1.8. DUN-2441 indicates the Testing and Irradiation Services Subsection has responsibility for post-irradiation 
examinations and measurements. Additional characterization of the test fuel elements after irradiation may reside in other records from that period, if needed.

\subsubsection{Material Data}

Table A-2 provides the initial uranium concentrations in the special test fuel elements. The reactor process tube number corresponds to a location for the fuel column in the B Reactor (Figure A-2). The fuel element number corresponds to the sequential position of the fuel element in the process tube with the first fuel element being closest to the rear end of the reactor. The specimen identification (ID) number corresponds to the results of isotopic analyses conducted on samples cut from the specified fuel element in the table (see Section 1.8).

TABLE A-2. INITIAL URANIUM ISOTOPIC CONCENTRATIONS IN PTA-069 SPECIAL TEST FUEL ELEMENTS

\begin{tabular}{|c|c|c|c|c|c|c|}
\hline $\begin{array}{l}\text { Reactor } \\
\text { PT } \\
\text { Number }\end{array}$ & $\begin{array}{l}\text { Fuel } \\
\text { Element } \\
\text { Number }\end{array}$ & $\begin{array}{l}\text { Specimen } \\
\text { ID Number }\end{array}$ & $\begin{array}{c}\mathrm{U}-234 \\
(\mathrm{wt} \%)^{\mathrm{a}}\end{array}$ & $\begin{array}{c}\mathrm{U}-235 \\
(\mathrm{wt} \%)^{b}\end{array}$ & $\begin{array}{c}\mathrm{U}-236 \\
(\mathrm{wt} \%)^{\mathrm{c}}\end{array}$ & $\begin{array}{c}\mathrm{U}-238 \\
(w t \%)^{d}\end{array}$ \\
\hline 1079 & 11 & 1 & 0.0050 & 0.7719 & 0.0410 & 99.2421 \\
\hline 1079 & 12 & 2 & 0.0050 & 0.7716 & 0.0006 & 99.2828 \\
\hline 1079 & 17 & 3 & 0.0050 & 0.7719 & 0.0410 & 99.2421 \\
\hline 1079 & 18 & 4 & 0.0050 & 0.7716 & 0.0006 & 99.2828 \\
\hline 1179 & 10 & 5 & 0.0050 & 0.7719 & 0.0410 & 99.2421 \\
\hline 1179 & 11 & 6 & 0.0050 & 0.7716 & 0.0006 & 99.2828 \\
\hline 1179 & 16 & 7 & 0.0050 & 0.7719 & 0.0410 & 99.2421 \\
\hline 1179 & 17 & 8 & 0.0050 & 0.7716 & 0.0006 & 99.2828 \\
\hline 1378 & 12 & 9 & 0.0050 & 0.7719 & 0.0410 & 99.2421 \\
\hline 1378 & 13 & 10 & 0.0050 & 0.7716 & 0.0006 & 99.2828 \\
\hline 0582 & 10 & 11 & 0.0050 & 0.7719 & 0.0410 & 99.2421 \\
\hline 0582 & 11 & 12 & 0.0050 & 0.7716 & 0.0006 & 99.2828 \\
\hline 0582 & 16 & 13 & 0.0050 & 0.7719 & 0.0410 & 99.2421 \\
\hline 0582 & 17 & 14 & 0.0050 & 0.7716 & 0.0006 & 99.2828 \\
\hline 1078 & 12 & 15 & 0.0050 & 0.7719 & 0.0410 & 99.2421 \\
\hline 1078 & 13 & 16 & 0.0050 & 0.7716 & 0.0006 & 99.2828 \\
\hline \multicolumn{7}{|c|}{$\begin{array}{l}\mathrm{c} \text { Uncertainty on } \mathrm{U}-236 \mathrm{wt} \%= \pm 0.0010 \text { for fuel with } 0.0410 \mathrm{wt} \% \mathrm{U}-236 \text {; and uncertainty on } \mathrm{U} \text { - } \\
236 \mathrm{wt} \%= \pm 0.0005 \text { for fuel with } 0.0006 \mathrm{wt} \% \mathrm{U}-236 \\
{ }^{\mathrm{d}} \text { Uncertainty in } \mathrm{U}-238 \mathrm{wt} \%+0.0020\end{array}$} \\
\hline
\end{tabular}


The fuel cladding on the special fuel elements for the PTA-069 experiment are fabricated from aluminum alloy cladding.

Relevant geometry and material data for the B Reactor can be found in Appendix B:

- Graphite moderated stack

- Reactor cooling

- Process tubes

- Reactor Control

- Fuel

\subsubsection{Temperature Information}

Inlet and outlet temperatures were continuously monitored on all process tubes with scram interlocks if the outlet temperature exceeded set values. (This did not occur in the process tubes containing the PTA-069 fuel elements.) The outlet temperatures were recorded daily for the PTA-069 experiment and are reported in DUN-3612-RD. The average inlet and outlet coolant temperatures are provided in Table A-3.

\subsubsection{Additional Information Relevant to Critical and Subcritical Measurements}

\subsubsection{Test Loading in B Reactor}

The locations of the process tubes used for the PTA-069 experiment in the B Reactor are shown graphically in Figure A-2. The figure identifies the locations for the PTA-069 experiment process tubes (identified as Test 1 in the figure). 
FIGURE A-2. LOCATION OF PROCESS TUBES COMPRISING THE PTA-069 EXPERIMENT IN THE B REACTOR

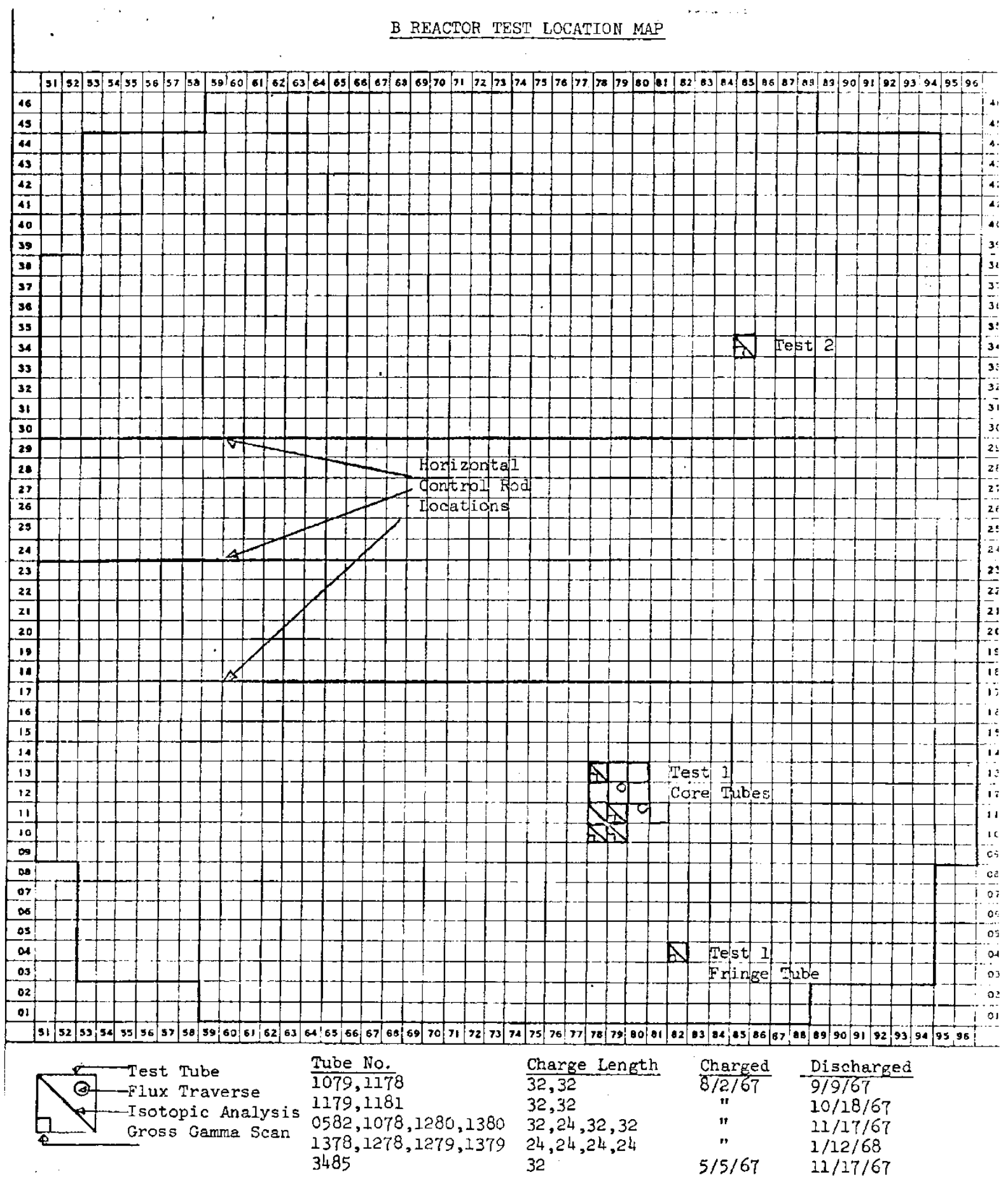




\subsubsection{Irradiation History for the PTA-069 Test}

Table A-3 summarizes the irradiation history for the PTA-069 experiment (data were taken from DUN-7243-RD). All process tubes were loaded (charged) into the B Reactor on August 2, 1967. The discharge dates for the process tubes correspond to different estimated exposures (MWD/ton).

TABLE A-3. OPERATING DATA FOR THE PTA-069 EXPERIMENT

\begin{tabular}{|c|c|c|c|c|c|c|c|c|c|c|}
\hline \multirow[b]{2}{*}{ PT \# } & \multirow{2}{*}{$\begin{array}{c}\text { Fuel } \\
\text { Ele- } \\
\text { ment \# }\end{array}$} & \multirow[b]{2}{*}{$\begin{array}{c}\text { Date } \\
\text { Charged }\end{array}$} & \multirow{2}{*}{$\begin{array}{c}\text { Date } \\
\text { Dis- } \\
\text { charged }\end{array}$} & \multirow{2}{*}{$\begin{array}{c}\text { Oper. } \\
\text { Full } \\
\text { Power } \\
\text { Days }\end{array}$} & \multirow{2}{*}{$\begin{array}{l}\text { Avg. } \\
\text { Tube } \\
\text { Pwr- } \\
\text { kw }\end{array}$} & \multirow{2}{*}{$\begin{array}{c}\text { Est. } \\
\text { Exp. } \\
\text { MWD/ } \\
\text { T }\end{array}$} & \multicolumn{2}{|c|}{$\begin{array}{c}\text { Water Temp. } \\
{ }^{\circ} \mathrm{C} \\
\end{array}$} & \multirow{2}{*}{$\begin{array}{l}\text { Avg. } \\
\text { Fuel } \\
\text { Pc. }\end{array}$} & \multirow{2}{*}{$\begin{array}{c}\text { Spec. } \\
\text { Pwr. } \\
\text { Kw/ft } \\
\text { Fuel Pc. }\end{array}$} \\
\hline & & & & & & & Inlet & Outlet & & \\
\hline \multirow[t]{4}{*}{1079} & 11 & $8 / 2 / 67$ & $9 / 9 / 67$ & 30 & 1059 & 285 & 19.9 & 98 & 69.6 & 50.5 \\
\hline & 12 & & & & & & & & 66.8 & 50.5 \\
\hline & 17 & & & & & & & & 53.7 & 76.0 \\
\hline & 18 & & & & & & & & 49.7 & 76.0 \\
\hline \multirow[t]{4}{*}{1179} & 10 & $8 / 2 / 67$ & $10 / 18 / 67$ & 55 & 1167 & 575 & 19.2 & 104 & 85.5 & 53.2 \\
\hline & 11 & & & & & & & & 82.4 & 56.8 \\
\hline & 16 & & & & & & & & 64.6 & 60.3 \\
\hline & 17 & & & & & & & & 60.6 & 99.4 \\
\hline \multirow[t]{2}{*}{1378} & 12 & $8 / 2 / 67$ & $1 / 12 / 68$ & 116 & 1239 & 1721 & 14.4 & 100 & 60.6 & 99.4 \\
\hline & 13 & & & & & & & & 55.9 & 91.7 \\
\hline \multirow[t]{4}{*}{0582} & 10 & $8 / 2 / 67$ & $11 / 17 / 67$ & 74 & 911 & 607 & 17.3 & 90 & 71.3 & 40.8 \\
\hline & 11 & & & & & & & & 68.9 & 40.8 \\
\hline & 16 & & & & & & & & 54.6 & 56.4 \\
\hline & 17 & & & & & & & & 51.4 & 54.0 \\
\hline \multirow[t]{2}{*}{1078} & 12 & $8 / 2 / 67$ & $11 / 17 / 67$ & 74 & 1153 & 1011 & 17.3 & 93 & 58.4 & 84.2 \\
\hline & 13 & & & & & & & & 54.3 & 84.2 \\
\hline
\end{tabular}

All 12 process tubes containing the PTA-069 experiment were charged into the B Reactor on August 2, 1967. 


\subsection{Description of Buckling and Extrapolation Length Measurements}

This section is not applicable for actinide integral cross-section benchmark.

\subsection{Description of Spectral Characteristics Measurements}

Two types of spectral characteristic measurements were performed for the PTA-069 experiment:

- Flux profile measurements in core locations near the process tubes containing the PTA069 experiment fuel elements

- Gamma scan profiles of the process tubes after discharge from the reactor

Axial neutron flux profiles were obtained from neighboring positions in the B Reactor. Specific axial profiles were obtained for reactor locations 1279 and 1180 in Figure A-2 and are shown in Figures A-3, Corrected Activity vs. Fuel Element Position for Reactor Location 1279, and A-4, Corrected Activity vs. Fuel Element Position for Reactor Location 1180, respectively. These positions were selected since they are next to the core process tube positions containing the PTA069 experiment test fuel elements (see Figure A-2). 
FLUX TRAVERSE PLOT

CORRECTED ACTIVITX VS, FUEL ELEMENT POSITION

Test Identiflcation: 1

Process Tube: 1279

Date: Jenuary 11, 1968

$\frac{D}{1}$
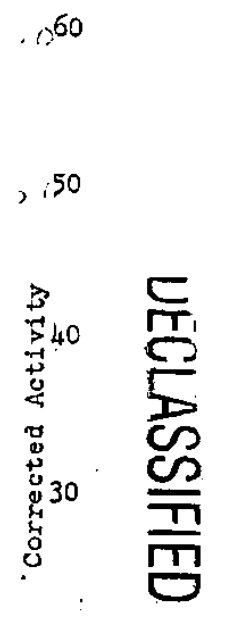

20

120

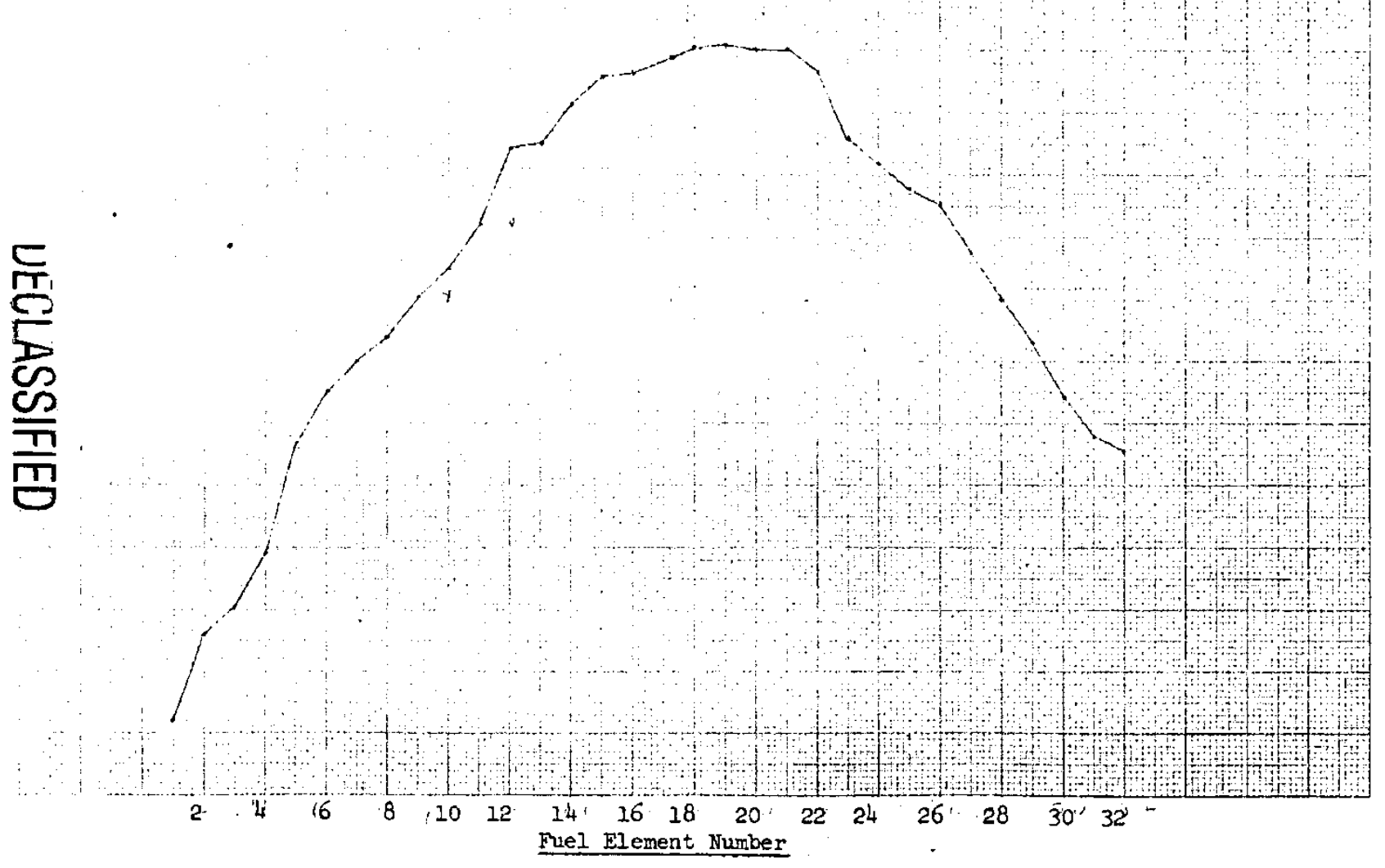


FLUX TRAVERSE PLOT

CORRECTED ACIIVITY VS. FUEL ELEMENT POSITION

$\stackrel{P}{I_{\omega}}$

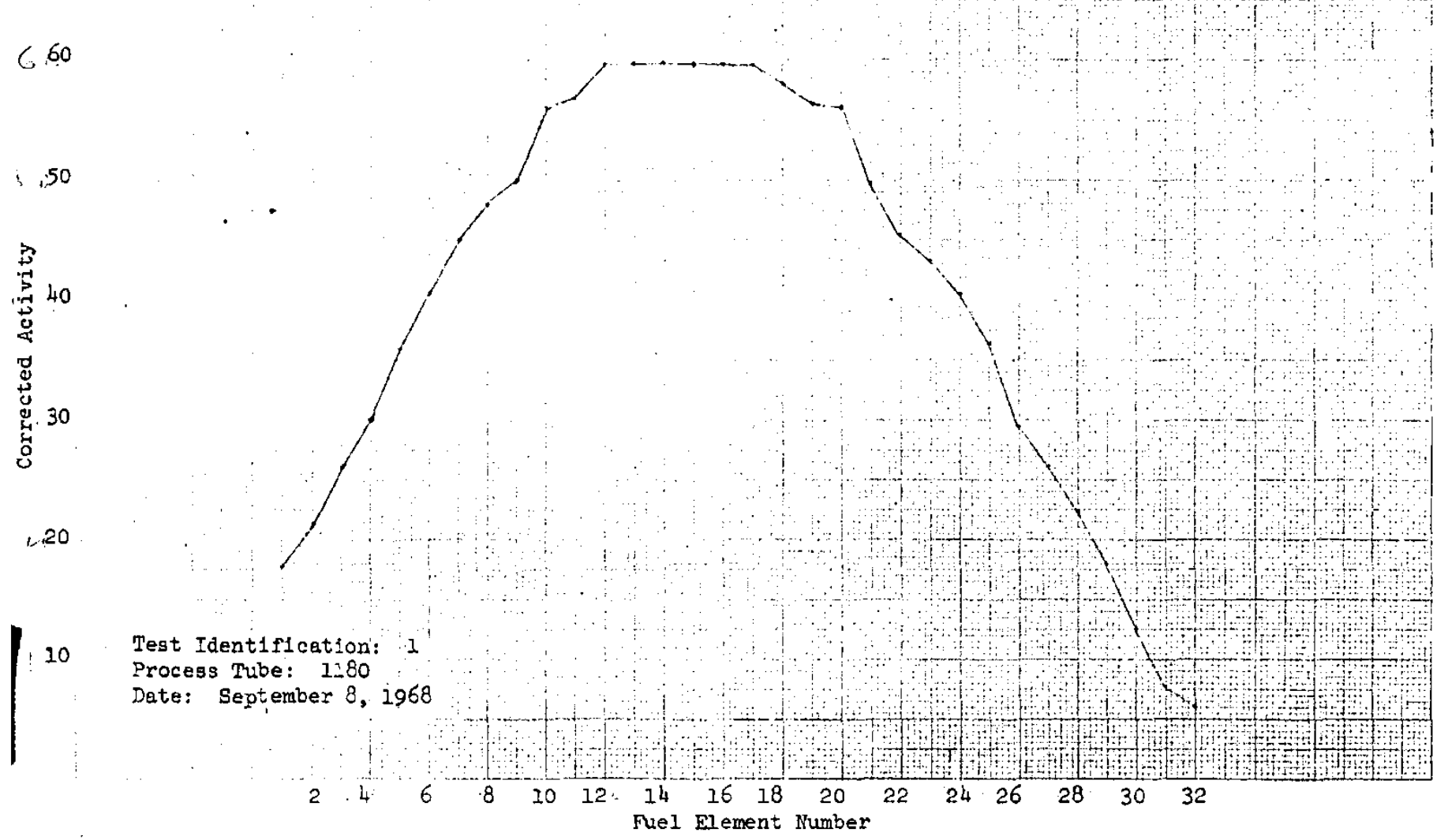


Gamma scans were conducted on the process tube fuel elements after they were discharged from the reactor. The gamma scans for selected process tubes $(0582,1078,1079,1179$, and 1378) are provided in Figures A.5 through A.9, respectively. These gamma scans were conducted after the unloading of the reactor at the end of the cycle and were made as the process tubes were discharged from the reactor. These gross gamma scans are relative to the background readings and provide an additional verification of similar exposure histories for the test elements.

\section{FIGURE A-5. RELATIVE GROSS GAMMA SCAN INTENSITY VS. FUEL ELEMENT POSITION FOR PROCESS TUBE 0582}

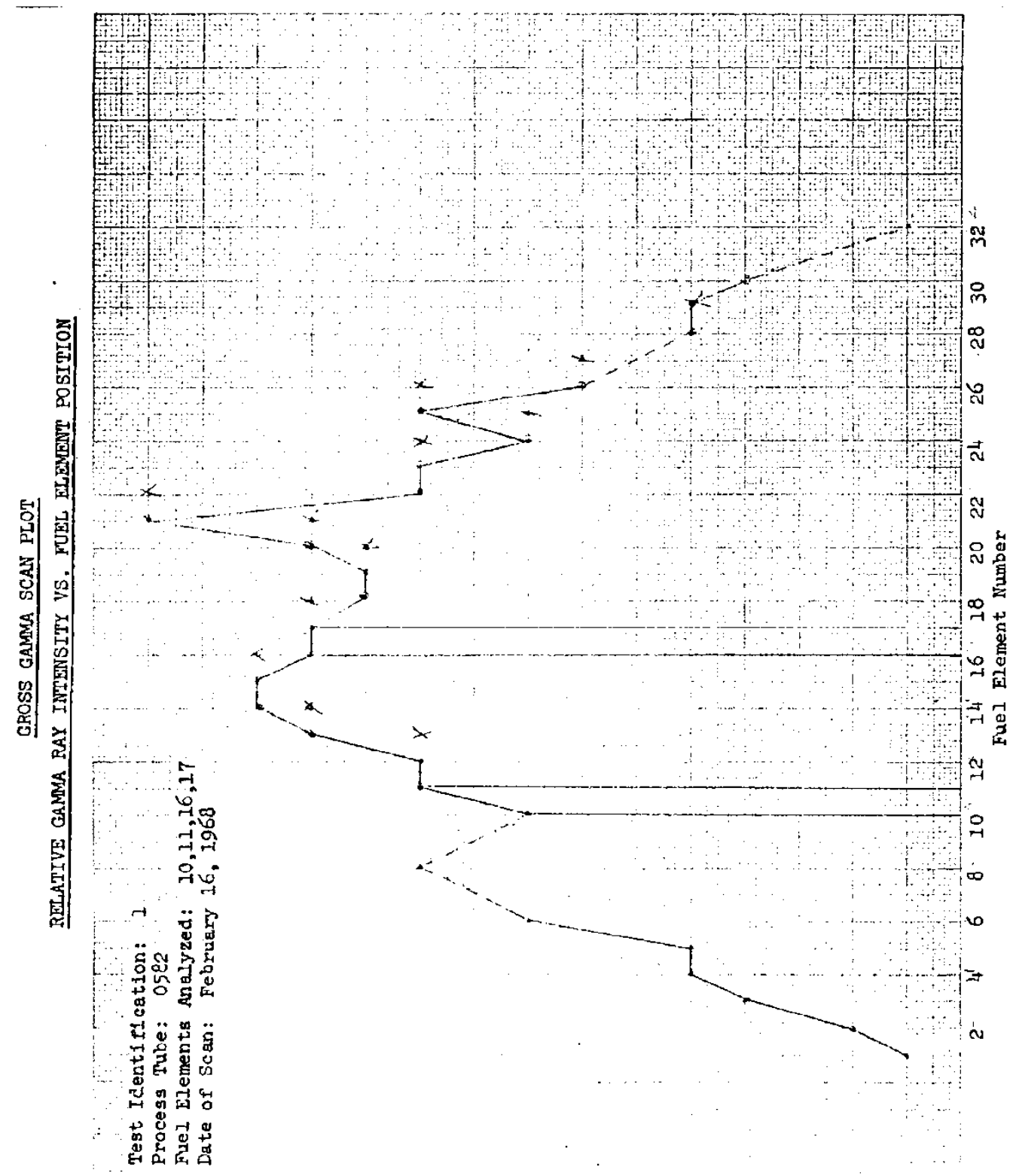

DECLASSIFIED

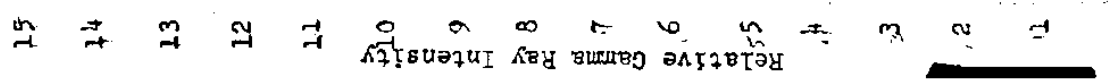


GROSS GAMMA SCAN PLOT

RELATIVE GAMMA RAY INTENSITY VS. FUEL ELEMENT POSITION

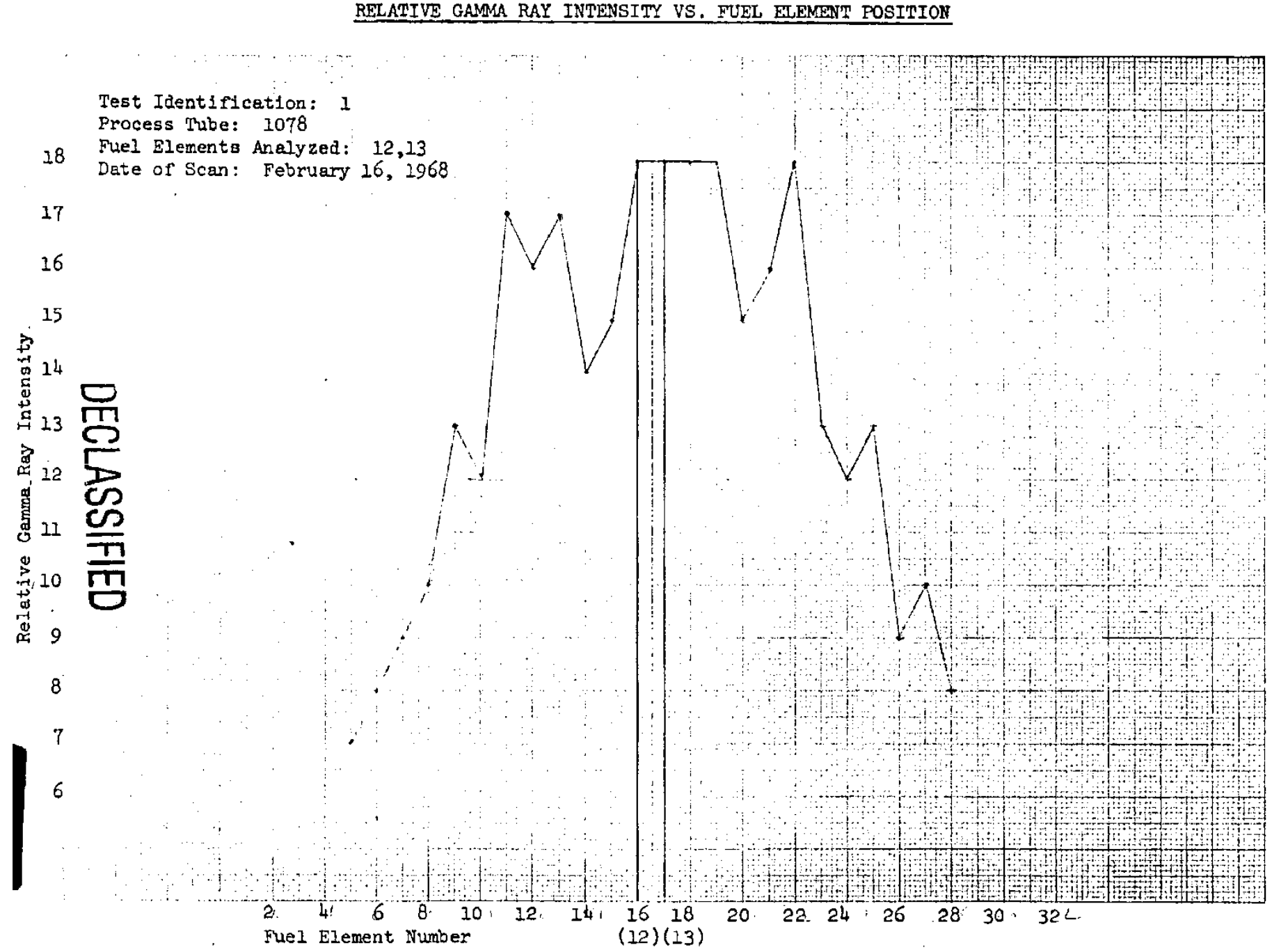




\section{CHPRC-01590, Revision 0}

FIGURE A-7. RELATIVE GROSS GAMMA SCAN INTENSITY VS. FUEL ELEMENT POSITION FOR PROCESS TUBE 1079

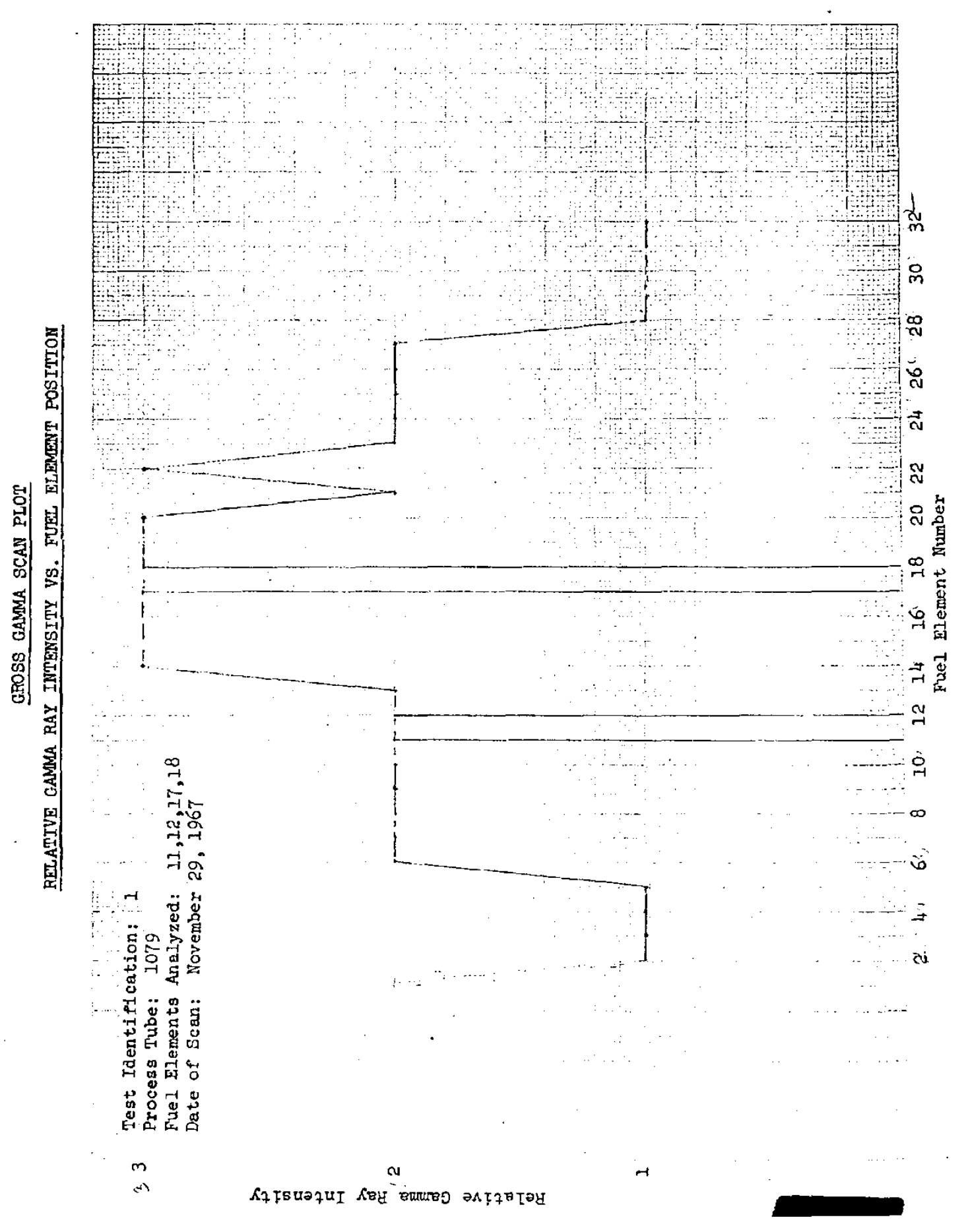


GROSS GAMMA SCAN PLOT

\section{RELATIVE GAMMA RAY IMTENSITY VS. FUEL ELEMENT POSITION}

Test Identification:

Process Tube: 1179

Fuel Elements Analyzed: $10,11,16,17$

Date of Scan: November 29, 1967

13

12

11

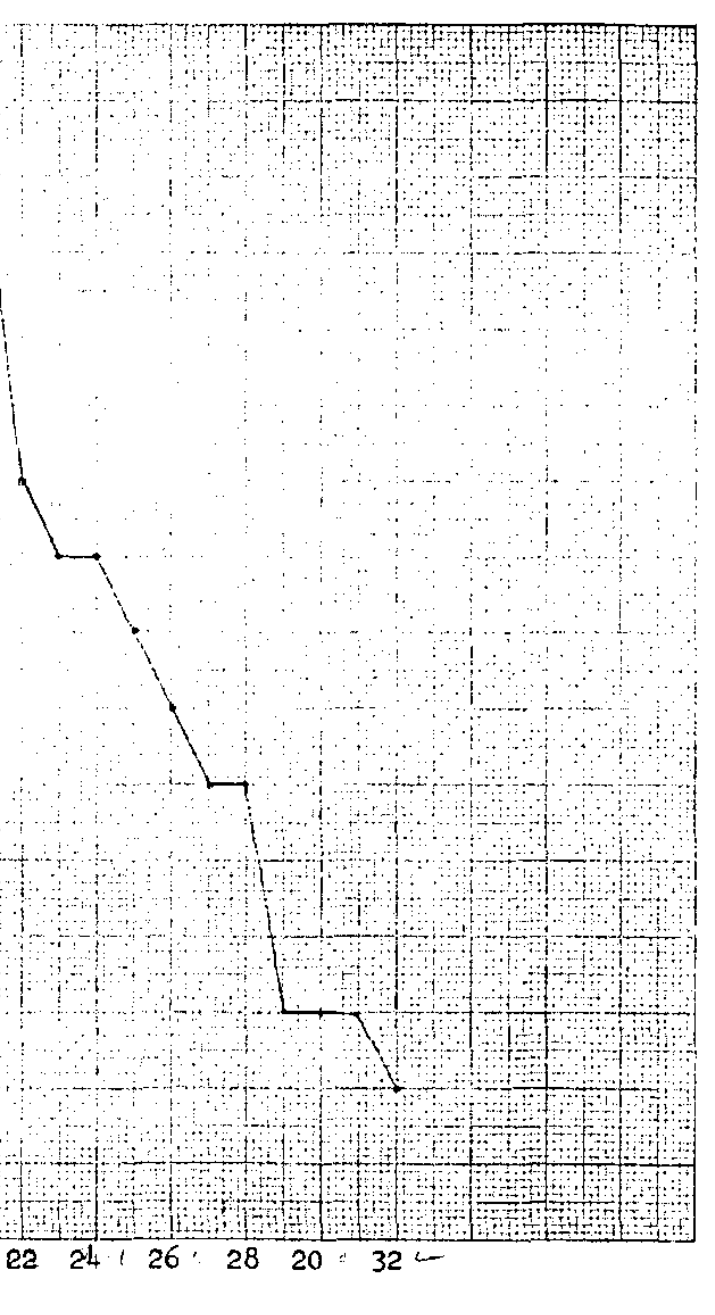


GROSS GAMMA SCAN PLOT

\section{RELATIVE GAMMA RAY INTENSITY VS, FUEL BLEMENT POSITTON}

Test Identification: I

Process Pube: 1378

Fuel Elements Analyzed: 12,13
Date of Scan: February 20,1968

10
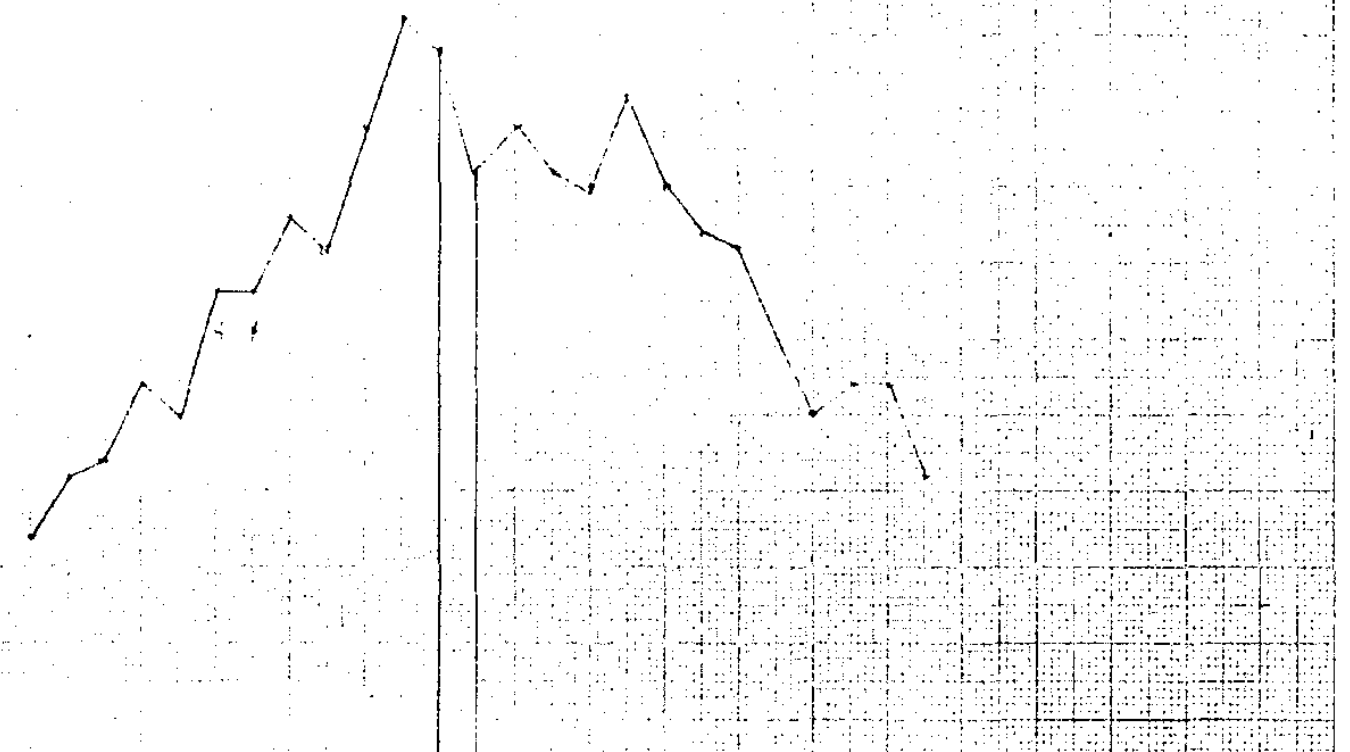

20
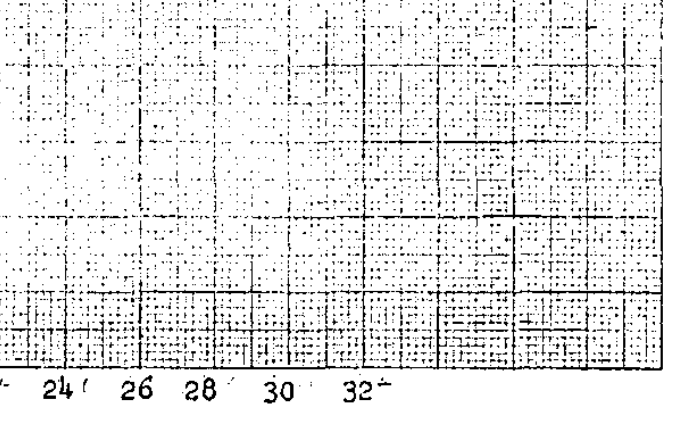
CHPRC-01590, Revision 0

\subsection{Description of Reactivity Effects Measurements}

This section is not applicable for actinide integral cross-section benchmark.

\subsection{Description of Reactivity Coefficient Measurements}

This section is not applicable for actinide integral cross-section benchmark.

\subsection{Description of Kinetics Measurements}

This section is not applicable for actinide integral cross-section benchmark.

\subsection{Description of Reaction-Rate Distribution Measurements}

This section is not applicable for actinide integral cross-section benchmark.

\subsection{Description of Power Distribution Measurements}

This section is not applicable for actinide integral cross-section benchmark.

\subsection{Description of Isotopic Measurements}

A total of 16 fuel elements were identified for post-irradiation examination to determine the isotopic content of the fuel after irradiation. The 16 fuel elements were selected as adjacent pairs of fuel elements with one element having the nominal $6 \mathrm{ppm} \mathrm{U-236} \mathrm{initial} \mathrm{concentration} \mathrm{and} \mathrm{the}$ second element having the nominal $400 \mathrm{ppm}$ U-236 initial concentration. Table A-3 provides the irradiation history for the fuel elements from the different process tubes.

The isotopic measurements were conducted on sliced fuel element samples taken from each fuel element. Following a cooling period for the fuel a thin, 1/16 of an inch thick, radial disc of fuel was cut from the center of each fuel element. This radial disc of fuel was dissolved and analyzed by mass spectroscopy for discharge yield and isotopic compositions. The individual heavy elements such as plutonium, uranium, neptunium, and fission products were separated by chemical means. Isotopic weight ratios for most of the plutonium and uranium isotopes were measured with a mass spectrometer. The Pu-238 and neptunium concentrations were determined by alpha counting techniques. The absolute concentrations of plutonium and uranium isotopes were measured with the isotope dilution technique.

Table A-4, Specimen ID\# and Radiochemical Record Numbers for PTQ-069 Experiment, from DUN-7243-RD provides a listing of the specific mass spectrometer and chemical analysis records for each radiochemical sample examined for the PTA-069 experiment. These data may be available in the record to provide additional clarification of post-irradiation measurement results, if needed.

Table A-5, Specimen ID\# and Radiochemical Record Numbers for PTA-069 Experiment, contains the uranium isotopic measurement results from the 16 fuel elements. Table A-6, Final 
$P u$ Isotopic Concentrations in Irradiated Fuel from the PTA-069 Experiment, contains the plutonium isotopic measurement results from the 16 fuel elements. Table A-7, Final Uranium, Plutonium, and Neptunium Concentrations, contains the final uranium, plutonium, and neptunium concentrations.

TABLE A-4. SPECIMEN ID\# AND RADIOCHEMICAL RECORD NUMBERS FOR PTA-069 EXPERIMENT

\begin{tabular}{|c|c|c|c|c|}
\hline $\begin{array}{c}\text { Speci- } \\
\text { men } \\
\text { ID \# }\end{array}$ & $\begin{array}{c}\text { Process } \\
\text { Tube } \\
\text { Number }\end{array}$ & $\begin{array}{c}\text { Fuel } \\
\text { Element } \\
\#\end{array}$ & $\begin{array}{c}\text { Mass Spec. Record \#s (U- } \\
\text { Pu) }\end{array}$ & $\begin{array}{c}\text { Chemical Analysis } \\
\text { Record \# }\end{array}$ \\
\hline 1 & 1079 & 11 & $1168009-1268011$ & 5194 \\
\hline 2 & 1079 & 12 & $1168011-1268013$ & 5195 \\
\hline 3 & 1079 & 17 & $1168013-1268015$ & 5196 \\
\hline 4 & 1079 & 18 & $1168015-1268017$ & 5197 \\
\hline 5 & 1179 & 10 & $1168040-1268043$ & 5337 \\
\hline 6 & 1179 & 11 & $1168042-1268045$ & 5338 \\
\hline 7 & 1179 & 16 & $1168044-1268047$ & 5339 \\
\hline 8 & 1179 & 17 & $1168046-1268049$ & 5340 \\
\hline 9 & 1378 & 12 & $1168251-1268205$ & 177 \\
\hline 10 & 1378 & 13 & $1168250-1268203$ & 176 \\
\hline 11 & 0582 & 10 & $1168265-1268219$ & 281 \\
\hline 12 & 0582 & 11 & $1168269-1268223$ & 283 \\
\hline 13 & 0582 & 16 & $1168263-1268217$ & 282 \\
\hline 14 & 0582 & 17 & $1168267-1268221$ & 174 \\
\hline 15 & 1078 & 12 & $116247-1268919$ & 175 \\
\hline 16 & 1078 & 13 & $116249-1268210$ & \\
\hline
\end{tabular}




\section{TABLE A-5. FINAL U ISOTOPIC CONCENTRATIONS IN IRRADIATED FUEL FROM THE PTA-069 EXPERIMENT}

\begin{tabular}{|c|c|c|c|c|c|c|c|c|}
\hline $\begin{array}{c}\text { Speci- } \\
\text { men } \\
\text { ID } \#\end{array}$ & $\begin{array}{c}\text { U-234 } \\
\text { (wt\%) }\end{array}$ & $\begin{array}{c}\text { U-234 } \\
\text { Uncert. } \\
\text { (wt\%) }\end{array}$ & $\begin{array}{c}\text { U-235 } \\
\text { (wt\%) }\end{array}$ & $\begin{array}{c}\text { U-235 } \\
\text { Uncert. } \\
\text { (wt\%) }\end{array}$ & $\begin{array}{c}\text { U-236 } \\
\text { (wt\%) }\end{array}$ & $\begin{array}{c}\text { U-236 } \\
\text { Uncert. } \\
\text { (wt\%) }\end{array}$ & $\begin{array}{c}\text { U-238 } \\
\text { (wt\%) }\end{array}$ & $\begin{array}{c}\text { U-238 } \\
\text { Uncert. } \\
\text { (wt\%) }\end{array}$ \\
\hline 1 & 0.00618 & 0.00060 & 0.6855 & 0.0070 & 0.04657 & 0.00100 & 99.2617 & 0.0070 \\
\hline 2 & 0.00510 & 0.00040 & 0.6690 & 0.0030 & 0.00730 & 0.00030 & 99.3190 & 0.0030 \\
\hline 3 & 0.00620 & 0.00040 & 0.6650 & 0.0030 & 0.4700 & 0.00100 & 99.2810 & 0.0030 \\
\hline 4 & 0.00510 & 0.00040 & 0.6600 & 0.0030 & 0.00840 & 0.00100 & 99.3270 & 0.0030 \\
\hline 5 & 0.00530 & 0.00030 & 0.6440 & 0.0040 & 0.01280 & 0.00050 & 99.3380 & 0.0040 \\
\hline $5^{*}$ & 0.00540 & 0.00030 & 0.6310 & 0.0040 & 0.01300 & 0.00050 & 99.3500 & 0.0040 \\
\hline 6 & 0.00720 & 0.00070 & 0.6400 & 0.0040 & 0.05200 & 0.00100 & 99.3000 & 0.0040 \\
\hline $6^{*}$ & 0.00670 & 0.00070 & 0.6330 & 0.0040 & 0.05200 & 0.00100 & 99.3100 & 0.0040 \\
\hline 7 & 0.00530 & 0.00050 & 0.6190 & 0.0030 & 0.01540 & 0.00040 & 99.3600 & 0.0030 \\
\hline 8 & 0.00610 & 0.0060 & 0.6180 & 0.0030 & 0.05400 & 0.00100 & 99.3210 & 0.0030 \\
\hline 9 & 0.00740 & 0.00050 & 0.5230 & 0.0040 & 0.07000 & 0.00100 & 99.3990 & 0.0050 \\
\hline 10 & 0.00530 & 0.00020 & 0.5140 & 0.0040 & 0.03200 & 0.00060 & 99.4490 & 0.0040 \\
\hline 11 & 0.00610 & 0.00030 & 0.6480 & 0.0040 & 0.01120 & 0.00050 & 99.3350 & 0.0040 \\
\hline 12 & 0.00620 & 0.00030 & 0.6170 & 0.0040 & 0.05500 & 0.00050 & 99.3220 & 0.0040 \\
\hline 13 & 0.00530 & 0.00020 & 0.6190 & 0.0040 & 0.01620 & 0.00050 & 99.3600 & 0.0040 \\
\hline 14 & 0.00640 & 0.00030 & 0.6290 & 0.0040 & 0.05300 & 0.00050 & 99.3120 & 0.0040 \\
\hline 15 & 0.00550 & 0.00020 & 0.5860 & 0.0040 & 0.02020 & 0.00060 & 99.3880 & 0.0040 \\
\hline 16 & 0.00620 & 0.00020 & 0.5880 & 0.0040 & 0.05990 & 0.00080 & 99.3460 & 0.0040 \\
\hline
\end{tabular}

\section{TABLE A-6. FINAL PU ISOTOPIC CONCENTRATIONS IN IRRADIATED FUEL FROM THE PTA-069 EXPERIMENT}

\begin{tabular}{|c|c|c|c|c|c|c|c|c|c|c|}
\hline $\begin{array}{c}\text { Spec- } \\
\text { imen } \\
\text { ID } \#\end{array}$ & $\begin{array}{c}\text { Pu-238 } \\
\text { (wt\%) }\end{array}$ & $\begin{array}{c}\text { Pu-238 } \\
\text { Uncert. } \\
\text { (wt\%) }\end{array}$ & $\begin{array}{c}\text { Pu-239 } \\
\text { (wt\%) }\end{array}$ & $\begin{array}{c}\text { Pu-239 } \\
\text { Uncert. } \\
\text { (wt\%) }\end{array}$ & $\begin{array}{c}\text { Pu-240 } \\
\text { (wt\%) }\end{array}$ & $\begin{array}{c}\text { Pu-240 } \\
\text { Uncert. } \\
\text { (wt\%) }\end{array}$ & $\begin{array}{c}\text { Pu- } \\
\mathbf{2 4 1} \\
\text { (wt\%) }\end{array}$ & $\begin{array}{c}\text { Pu-241 } \\
\text { Uncert. } \\
\text { (wt\%) }\end{array}$ & $\begin{array}{c}\text { Pu-242 } \\
\text { (wt\%) }\end{array}$ & $\begin{array}{c}\text { Pu-242 } \\
\text { Uncert. } \\
\text { (wt\%) }\end{array}$ \\
\hline 1 & 0.0094 & 0.0010 & 96.5860 & 0.0200 & 3.2520 & 0.0200 & 0.1678 & 0.0050 & 0.01240 & 0.00100 \\
\hline 2 & 0.0059 & 0.0006 & 96.5300 & 0.0200 & 3.3400 & 0.0200 & 0.1320 & 0.0030 & 0.0000 & 0.00000 \\
\hline 3 & 0.0067 & 0.0007 & 96.1300 & 0.0200 & 3.6600 & 0.0200 & 0.1610 & 0.0060 & 0.0050 & 0.01000 \\
\hline 4 & 0.0043 & 0.0004 & 95.8300 & 0.0400 & 4.0000 & 0.0400 & 0.1730 & 0.0090 & 0.0000 & 0.00000 \\
\hline 5 & 0.0000 & 0.0010 & 93.2200 & 0.0300 & 6.3450 & 0.0300 & 0.4200 & 0.0080 & 0.01200 & 0.01000 \\
\hline $5^{*}$ & 0.0097 & 0.0010 & -- & -- & -- & -- & -- & -- & -- & -- \\
\hline 6 & 0.0000 & 0.0015 & 93.5600 & 0.0300 & 6.0220 & 0.0300 & 0.4010 & 0.0080 & 0.01300 & 0.00100 \\
\hline $6^{*}$ & 0.0150 & 0.0020 & -- & -- & -- & -- & -- & -- & -- & -- \\
\hline 7 & 0.0120 & 0.0012 & 92.1300 & 0.0400 & 7.2700 & 0.0400 & 0.5800 & 0.0100 & 0.01900 & 0.00200 \\
\hline 8 & 0.0200 & 0.0020 & 91.9900 & 0.0400 & 7.3900 & 0.0400 & 0.5900 & 0.0100 & 0.02100 & 0.00400 \\
\hline 9 & 0.0550 & 0.0055 & 82.2600 & 0.0800 & 15.3700 & 0.0800 & 2.1800 & 0.0100 & 0.18500 & 0.00600 \\
\hline 10 & 0.0330 & 0.0033 & 82.3700 & 0.0800 & 15.2800 & 0.0800 & 2.1700 & 0.0100 & 0.18700 & 0.00600 \\
\hline 11 & 0.0095 & 0.0010 & 95.0900 & 0.0300 & 4.6400 & 0.0300 & 0.2610 & 0.0020 & 0.00760 & 0.00700 \\
\hline 12 & 0.0190 & 0.0019 & 92.5300 & 0.0300 & 6.8800 & 0.0300 & 0.5720 & 0.0030 & 0.02000 & 0.00100 \\
\hline 13 & 0.0120 & 0.0012 & 92.4900 & 0.0300 & 6.9000 & 0.0300 & 0.5740 & 0.0050 & 0.02900 & 0.00200 \\
\hline 14 & 0.0150 & 0.0015 & 93.6800 & 0.0300 & 5.8800 & 0.0300 & 0.4280 & 0.0040 & 0.01800 & 0.00100 \\
\hline 15 & 0.0150 & 0.0015 & 89.8100 & 0.0500 & 9.2200 & 0.0500 & 0.9220 & 0.0050 & 0.04300 & 0.00100 \\
\hline 16 & 0.0270 & 0.0027 & 89.5400 & 0.0500 & 9.4600 & 0.0500 & 0.9510 & 0.0050 & 0.04400 & 0.00100 \\
\hline
\end{tabular}


CHPRC-01590, Revision 0

\section{TABLE A-7. FINAL URANIUM, PLUTONIUM, AND NEPTUNIUM CONCENTRATIONS}

\begin{tabular}{|c|c|c|c|c|c|c|}
\hline $\begin{array}{c}\text { Speci- } \\
\text { men } \\
\text { ID \# }\end{array}$ & $\begin{array}{c}\text { Uranium } \\
(\mathbf{g} / \mathbf{L})\end{array}$ & $\begin{array}{c}\text { Uranium } \\
\text { Uncert. } \\
(\mathbf{g} / \mathbf{L})\end{array}$ & $\begin{array}{c}\text { Plutonium } \\
(\mathbf{g} / \mathbf{L})\end{array}$ & $\begin{array}{c}\text { Plutonium } \\
\text { Uncert. } \\
(\mathbf{g} / \mathbf{L})\end{array}$ & $\begin{array}{c}\text { Neptunium } \\
(\mathbf{g} / \mathbf{L})\end{array}$ & $\begin{array}{c}\text { Neptunium } \\
\text { Uncert. } \\
(\mathbf{g} / \mathbf{L})\end{array}$ \\
\hline 1 & 264.0 & 6.60 & 0.1350 & 0.0034 & 0.000980 & 0.000049 \\
\hline 2 & 359.0 & 8.970 & 0.1360 & 0.0034 & 0.000540 & 0.000027 \\
\hline 3 & 336.0 & 8.40 & 0.1430 & 0.0036 & 0.001110 & 0.000055 \\
\hline 4 & 400.0 & 10.00 & 0.1750 & 0.0044 & 0.000780 & 0.000039 \\
\hline 5 & 226.0 & 5.65 & 0.1640 & 0.0041 & 0.000670 & 0.000033 \\
\hline $5^{*}$ & 257.0 & 6.42 & 0.1630 & 0.0041 & 0.000800 & 0.000040 \\
\hline 6 & 146.0 & 3.65 & 0.1090 & 0.0027 & 0.000840 & 0.000042 \\
\hline $6^{*}$ & 158.0 & 3.95 & 0.1020 & 0.0025 & 0.001240 & 0.000062 \\
\hline 7 & 211.0 & 5.270 & 0.1990 & 0.0050 & 0.001030 & 0.000051 \\
\hline 8 & 218.0 & 5.45 & 0.1790 & 0.0045 & 0.001800 & 0.000090 \\
\hline 9 & 182.0 & 4.55 & 0.3470 & 0.0087 & 0.003190 & 0.000160 \\
\hline 10 & 166.0 & 4.15 & 0.3090 & 0.0077 & 0.001860 & 0.000093 \\
\hline 11 & 149.0 & 3.72 & 0.0930 & 0.0023 & 0.000423 & 0.000021 \\
\hline 12 & 126.0 & 3.15 & 0.1110 & 0.0028 & 0.000930 & 0.000046 \\
\hline 13 & 116.0 & 2.90 & 0.1060 & 0.0027 & 0.000541 & 0.000027 \\
\hline 14 & 127.0 & 3.18 & 0.0992 & 0.0025 & 0.000800 & 0.000040 \\
\hline 15 & 176.0 & 4.40 & 0.2270 & 0.0057 & 0.001060 & 0.000053 \\
\hline 16 & 260.0 & 6.50 & 0.2920 & 0.0073 & 0.002630 & 0.000130 \\
\hline
\end{tabular}

\subsection{Description of Other Miscellaneous Types of Measurements}

This section is not applicable for actinide integral cross-section benchmark.

\subsection{EVALUATION OF EXPERIMENTAL DATA}

\subsection{Evaluation of Critical and / or Subcritical Configuration Data}

Critical to the judgment that this information provides sufficient information to be used as benchmark for actinide production is an evaluation of the data used to describe the reactor environment for the experiment. Appendix B provides an adequate physical description for the irradiation environment. Also the pertinent material information for the relevant core components is provided.

Relevant information includes specific fuel loading for fuel adjacent to the process tubes containing the PTA-069 experiment. While most of the standard fuel in the B Reactor was natural uranium, there is evidence that some SPR core loadings may have included enriched $(0.95 \mathrm{wt} \% \mathrm{U}-235)$ fuel in the fringe of the core to improve flux flattening within the core. Such fuel may have been adjacent to the process tube location 0582 . These data should be available from the records; however, they have not been found, as of this date, for this experiment. 
Data which may still need to be pursued include:

- Specific core loadings for the time period the PTA-069 experiment was loaded in the B Reactor,

- The burn-up in the fuel for the process tubes in the immediate area of the experimental process tubes, and

- The degree of non-uniformity in the graphite stack during the experiment irradiation.

Cycle specific core loading information for the B Reactor and effective fuel burn-up in the process tubes in the immediate vicinity of the experimental process tube locations should be available in the Hanford records.

The degree of non-uniformity in the graphite stack near the experiment's process tubes is not accurately known. While general information of the graphite dimensional deformation exists, the specifics are not. Perhaps some core section modeling could provide some insight into the impact of this effect on actinide production results.

\subsection{Evaluation of Buckling and Extrapolation Length Data}

This section is not applicable for actinide integral cross-section benchmark.

\subsection{Evaluation of Spectral Characteristics Data}

The available spectral information includes both axial flux profiles at two in-core process tube positions and gamma scans on five process tube positions. The gamma scans for process tube locations $1078,1079,1179$, and 1378 agree qualitatively with the axial flux profile data for the process tube locations 1180 and 1279 . The differences in the relative magnitudes for the different process tube locations can be attributed to the times at which the gamma scans were performed. These data can provide corroborative information when developing a model for the B Reactor neutron flux environment.

\subsection{Evaluation or Reactivity Effects Data}

This section is not applicable for actinide integral cross-section benchmark.

\subsection{Evaluation of Reactivity Coefficient Data}

This section is not applicable for actinide integral cross-section benchmark.

\subsection{Evaluation of Kinetics Data}

This section is not applicable for actinide integral cross-section benchmark. 
CHPRC-01590, Revision 0

\subsection{Evaluation of Reaction-Rate Distribution Data}

This section is not applicable for actinide integral cross-section benchmark.

\subsection{Evaluation of Power Distribution Data}

This section is not applicable for actinide integral cross-section benchmark.

\subsection{Evaluation of Isotopic Data}

The radiochemical data summarized in Section 1.9 provides adequate information for consideration as a benchmark-quality. The data is reported with uncertainties reported in DUN7243-RD. A review of the original radiochemical analyses reports provided in Table A-. 4 may be useful in providing additional insight into the meaning of the uncertainties quoted in the reference. Additional information on the specific techniques used at that time would be useful in providing an independent assessment of this data quality.

\subsection{Evaluation of Other Miscellaneous Types of Data}

This section is not applicable for actinide integral cross-section benchmark.

\subsection{REFERENCES}

DUN-2441, J.P. Schmitt and H. Toffer, PTA-069-Neptunium-237 Production from Natural Uranium with a High U-236 Content, Douglas United Nuclear, Inc, Richland, Washington, May, 1967.

DUN-3612 RD, A. F. Kupinski, Working Papers - PTA-069, Douglas United Nuclear, Inc, Richland, Washington, January 1968

DUN 7243 RD, H. Toffer and A. F. Kupinski, Experimental Isotopic Analysis of Point Exposure Data in Hanford Production Reactor Fuels, Douglas United Nuclear, Inc, Richland, Washington, September 1970. 
CHPRC-01590, Revision 0

APPENDIX B

B REACTOR RELEVANT INFORMATION 
CHPRC-01590, Revision 0

This page is intentionally left blank. 


\section{B1.0 SUMMARY DESCRIPTION}

Appendix B provides a summary description for the B Reactor and includes relevant data that would be used to develop a model for the reactor. This includes information on the Graphite Moderated Stack, the Process Tube Assembly, and the Fuel.

\section{B2.0 GRAPHITE MODERATED STACK}

Nominal dimensions for the B Reactor graphite stack are: front to rear -28 feet, top to bottom 36 feet, and side to side -36 feet. The stack is made up of graphite blocks that are nominally 4$3 / 16$ inches square by 48 inches long. These nuclear grade graphite blocks are 99.99 percent carbon.

The graphite blocks are stacked in layers with the long dimension within a layer parallel and at right angles to the long dimension of the blocks in the adjacent layers (Figure B-1, B Reactor Graphite Stack Keying and Selected Dimensions). Block joints are staggered to provide greater stability in the stack. The bottom graphite layer rests on a carefully leveled layer of cast iron blocks which is used as a thermal shield. The cast iron blocks are grouted on top of a massive concrete foundation for the reactor. Alternate blocks in the front to rear layers are pierced for process tubes giving a total of 2004 process tubes in the B reactor. This corresponds to a centerto-center lattice spacing of 8.375 inches for the process tubes. .

Additional penetrations into the graphite stack include:

- Vertical Safety Rod Channels - 29 vertical channels from the top to the bottom of the stack.

- Horizontal Control Rod Channels - nine horizontal rod channels penetrating from the left side of the stack when facing the front face and extending through the process tube pattern in the stack.

The B Reactor graphite stack has experienced distortion due to unequal growth or contraction of the graphite during irradiation. A typical tube channel vertical transverse shows the graphite in the outer edges of the stack to have expanded, while the core has contracted. The displacements are as much as 1 to 2 inches expansion and 1-1/2 to 3 inches contraction. This distortion in the tube channels has resulted in the necessity of enlarging or broaching the channels when process tubes are replaced in some of the more severely distorted channels. Transverses in the vertical rod channels show the center of the graphite stack to be contracting inward. The movement is more pronounced in the side-to-side direction than in the front to rear. The vertical safety rod systems have been affected to the extent that flexible safety rods have been installed in some of the more severely distorted channels. 


\section{FIGURE B-1. B REACTOR GRAPHITE STACK KEYING AND SELECTED DIMENSIONS}

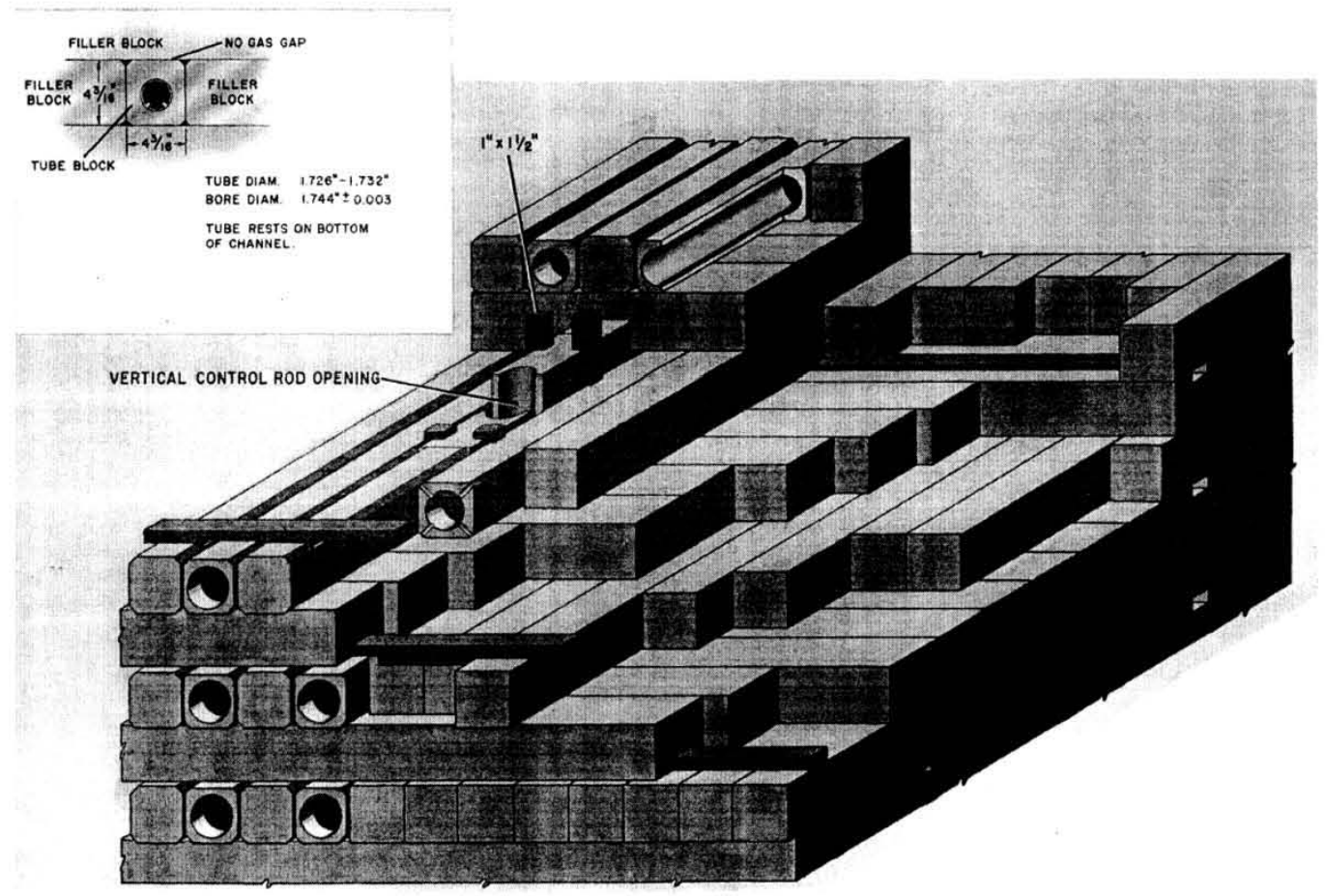

\section{B3.0 PROCESS TUBE ASSEMBLY}

The process tube assembly is made up of the inlet and outlet gunbarrel assemblies, the process tube, and the inlet and outlet nozzle assemblies. The gunbarrel assemblies support and protect the process tube as it passes through the biological and thermal shield. Process tube endconnections are made to the gunbarrels through flanges which prevent water from leaking into the graphite stack and the gas atmosphere from leaking out. The nozzle assemblies are connected to and supported by the gunbarrel. The end of the nozzle assembly has a removable cap provided for charging fuel elements and test elements into the process tube.

The cross-section for the process tube is shown in Figure B-2, Process Tube Cross-Section. There are two ribs on the bottom of the tube, 45 degrees from the vertical, which support the fuel elements and provide passage of the cooling water under the fuel elements. Original process tubes did not have a uniform wall thickness because of limitations in aluminum extrusion technology. Manufacturing processes have improved and currently (1963) all tubes are being 
received with a uniform wall design. The minimum wall thickness of the process tube is 55 mils and is fabricated from 1100 aluminum alloy. 


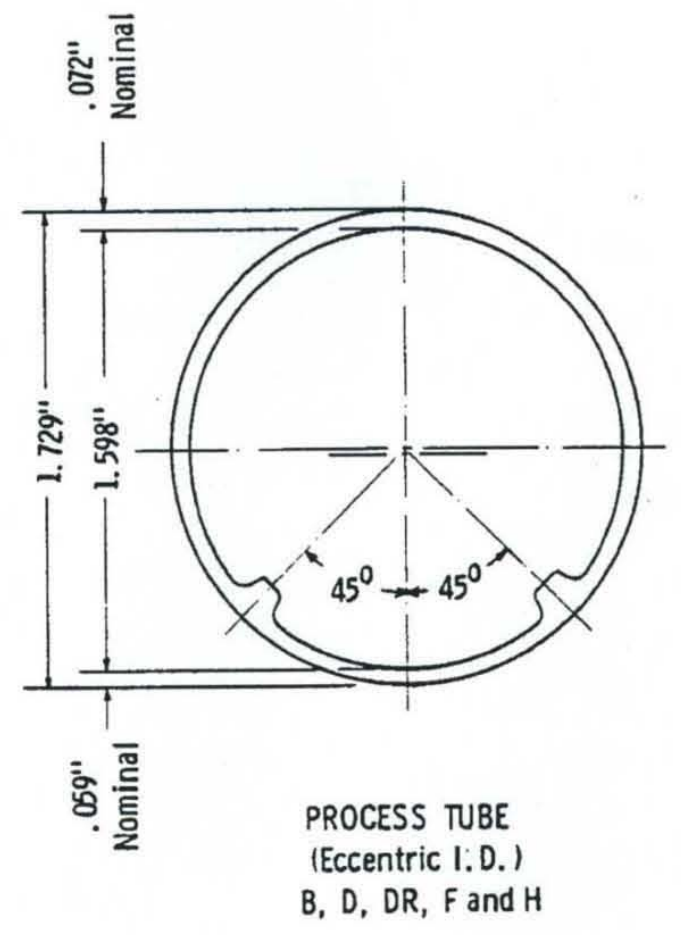

\section{B4.0 FUEL}

The B Reactor fuel is predominately natural uranium metal. To provide excess reactivity and power flattening, enriched uranium fuel $(0.947 \mathrm{w} \% \mathrm{U}-235)$ has been used in later reactor operations.

The fuel geometry is tubular, enabling coolant to flow within the fuel as well as outside of it. The cladding is aluminum alloy bonded to the uranium by a layer of eutectic aluminum-silicon alloy. The dimensions and types of fuel elements used in B Reactor are shown in Figure B-1. Aluminum spacers are used to position the fuel charge within the active zone of the reactor. These spacers are tubular with either perforated or solid walls. They are generally eight inches in length, although some five inch perforated spacers are utilized. To prevent obstruction of flow perforated spacers are used adjacent to the fuel charge and in the rear nozzle.

\section{B5.0 RELEVANT REACTOR PARAMETERS}

The appropriate lattice dimensions and physical properties of the lattice materials are listed in Tables B-1, Lattice Dimensions, and B-2, Lattice Composition. 
CHPRC-01590, Revision 0

TABLE B-1. LATTICE DIMENSIONS

\begin{tabular}{|l|l|}
\hline Parameter & Dimension \\
\hline Lattice geometry & Square \\
\hline Lattice spacing (inches) & 8.375 \\
\hline Equivalent cell radius (inches) & 4.725 \\
\hline Process Tube O.D. (inches) & 1.728 \\
\hline${\text { Process Tube I.D. }{ }^{\text {a }} \text { (inches) }}$ & 1.598 \\
\hline Fuel dimensions $^{\text {(see Table A- }}$ \\
\hline $\begin{array}{l}\text { a Average dimensions: tubes are not quite } \\
\text { circular and contain ribs }\end{array}$ \\
\hline
\end{tabular}

TABLE B-2. LATTICE COMPOSITION

\begin{tabular}{|l|c|}
\hline \multicolumn{1}{|c|}{ Material } & $\begin{array}{c}\text { Density at room temperature } \\
\left(\mathrm{gm} / \mathrm{cm}^{3}\right)\end{array}$ \\
\hline Coolant water & 1.0 \\
\hline Aluminum (fuel cladding) ${ }^{\mathrm{a}}$ & 2.70 \\
\hline${ }^{\text {Aluminum (process tube) }}{ }^{\mathrm{b}}$ & 2.70 \\
\hline Graphite $^{\mathrm{c}}$ & $1.61-1.68^{\mathrm{c}}$ \\
\hline${ }^{\mathrm{a}}$ Aluminum Alloy \\
\hline${ }^{\mathrm{b}} 1100$ Alloy \\
\hline $\begin{array}{l}{ }^{\mathrm{c}} \text { Range given covers all six SPR reactors. Density is average } \\
\text { over reactor thus taking into account voids }\end{array}$ \\
\hline
\end{tabular}

